Supporting Information for:

\title{
Improved Catalytic Activity and Stability of a Palladium Pincer Complex by Incorporation into a Metal-organic Framework
}

Samantha A. Burgess, Abebu Kassie, Sarah A. Baranowski, Keith J. Fritzsching, Klaus SchmidtRohr, Craig M. Brown, Casey R. Wade* cwade@brandeis.edu

Table of contents:

Materials and General Considerations

Synthesis of $\mathbf{E t}_{2} \mathbf{N P}\left(\mathbf{C}_{6} \mathbf{H}_{5}-\mathbf{C O O}^{t} \mathbf{B u}\right)_{2}$

Synthesis of $\mathbf{C I P}\left(\mathrm{C}_{6} \mathrm{H}_{5}-\mathrm{COO}^{t} \mathrm{Bu}\right)_{2}$

Synthesis of ${ }^{\mathrm{t}} \mathbf{B u}_{4}(\mathbf{L}-\mathbf{P d I})$

Synthesis of $\mathbf{H}_{\mathbf{4}}(\mathbf{L}-\mathbf{P d I})$

Synthesis of 1-X

Synthesis of 1-TFA

Synthesis of ${ }^{t} \mathbf{B u}_{4}(\mathbf{L}-\mathbf{P d C l})$

Synthesis of ${ }^{\mathrm{t}} \mathbf{B u}_{4}(\mathbf{L}-\mathbf{P d T F A})$

Reaction of ${ }^{\mathrm{t}} \mathbf{B u}_{4}\left(\mathbf{L}\right.$-PdTFA) with $\mathrm{HCO}_{2} \mathrm{Na}$.

General procedure for catalytic hydrogenation of aldehydes

Table S1. Catalytic Transfer Hydrogenation of Aldehydes with 1-TFA.

Figure S1. Structures of 1-X showing four-fold disorder of the $[\mathrm{L}-\mathrm{PdX}]^{4-}$ linkers.

Figure S2. PXRD patterns of 1-X after treatment with aqueous acid and base.

Figure S3. TGA data for 1-X.

Figure S4. $\mathrm{N}_{2}$ adsorption isotherm $(77 \mathrm{~K})$ of $\mathbf{1 - X}$.

Figure S5. MAS ${ }^{31} \mathrm{P}$ NMR spectrum of $\mathbf{1 - X}$ showing peak

deconvolution of major resonance.

Figure S6. PXRD patterns of 1-X and 1-TFA.

Figure S7. Overlay of the MAS ${ }^{13} \mathrm{C}$ NMR spectra of $\mathbf{H}_{\mathbf{4}}(\mathbf{L}-\mathbf{P d I}), \mathbf{1 - X}$,

1-TFA, and 1-TFA after catalysis.

Figure S8. $\mathrm{N}_{2}$ adsorption isotherm of 1-TFA.

Figure S9. PXRD patterns of 1-TFA before and after catalysis.

Figure S10. Overlay of the MAS ${ }^{31} \mathrm{P}$ NMR spectra of $\mathbf{H}_{4}(\mathbf{L}$-PdI), 1-X, 1-TFA, and 1-TFA after catalysis.

Figure S11. ${ }^{31} \mathrm{P}\left\{{ }^{1} \mathrm{H}\right\}$ and ${ }^{1} \mathrm{H}$ NMR spectra of $\left({ }^{\mathrm{t}} \mathrm{BuO}{ }_{2} \mathrm{CPh}\right)_{2} \mathrm{P}(\mathrm{O}) \mathrm{OCD}_{3}$ isolated from reaction of ${ }^{\mathrm{t}} \mathbf{B u}_{4}\left(\mathbf{L}\right.$-PdTFA) with 4 equiv. of $\mathrm{HCO}_{2} \mathrm{Na}$ in $\mathrm{CD}_{3} \mathrm{OD}$. page number

S3

S5

S6

S7

S8

S9

S10

S11

S12

S13

S14

S15

S16

S17

S18

S19

S20

S21

S22

S23

S24

S25

S26 
Figure S12. ESI mass spectrum of $\left({ }^{\mathrm{t}} \mathrm{BuO}_{2} \mathrm{CPh}\right)_{2} \mathrm{P}(\mathrm{O}) \mathrm{OCD}_{3}$ isolated from reaction of ${ }^{\mathbf{t}} \mathbf{B u}_{4}\left(\mathbf{L}\right.$-PdTFA) with 4 equiv. of $\mathrm{HCO}_{2} \mathrm{Na}$ in $\mathrm{CD}_{3} \mathrm{OD}$.

Figure S13. ${ }^{31} \mathrm{P}\left\{{ }^{1} \mathrm{H}\right\}$ and ${ }^{1} \mathrm{H}$ NMR spectra of $\left({ }^{t} \mathrm{BuO}_{2} \mathrm{CPh}\right)_{2} \mathrm{P}(\mathrm{O}) \mathrm{OCH}_{3}$ isolated from reaction of ${ }^{\mathbf{t}} \mathbf{B u}_{4}(\mathbf{L}-\mathbf{P d T F A})$ with 4 equiv. of $\mathrm{HCO}_{2} \mathrm{Na}$ in $\mathrm{CH}_{3} \mathrm{OH}$.

Figure S14. ${ }^{1} \mathrm{H}$ NMR spectrum of an acid-digested sample of activated 1-X. $\quad$ S29

Figure S15. MAS ${ }^{31} \mathrm{P}$ NMR spectrum of an activated sample of 1-X. $\quad$ S30

Figures S16-S20. ${ }^{1} \mathrm{H}$ NMR spectra of $\mathrm{CDCl}_{3}$ extracted products from select catalytic transfer hydrogenation reactions listed in Table 1.

Figure S21. ${ }^{1} \mathrm{H}$ NMR spectrum of aliquot of reaction mixture (before hot filtration)

extracted with $\mathrm{CDCl}_{3}$ after $3 \mathrm{~h}$.

Figure S22. ${ }^{1} \mathrm{H}$ NMR spectrum of products extracted with $\mathrm{CDCl}_{3}$ after hot filtration at $3 \mathrm{~h}$ and continued heating of filtrate for $13 \mathrm{~h}$ at $60{ }^{\circ} \mathrm{C}$.

Figures S23-S32. ${ }^{1} \mathrm{H}$ NMR spectra of $\mathrm{CDCl}_{3}$ extracted products after catalytic transfer hydrogenation of substrates listed in Table S1.

Synchrotron Powder Diffraction and Rietveld Refinement of 1-X.

Figure S33. Observed, calculated, and difference profiles from the Rietveld refinement of 1-X from synchrotron PXRD data

Figure S34. Fourier difference scattering density of the un-modeled solvent in the pores of $\mathbf{1 - X}$. 


\section{Experimental Details}

Materials and General Considerations. tert-butyl-4-bromobenzoate, ${ }^{\mathrm{S} 1}\left(\mathrm{Et}_{2} \mathrm{~N}\right) \mathrm{PCl}_{2},{ }^{\mathrm{S} 2}$ 2iodoresorcinol, ${ }^{\mathrm{S} 3} \mathrm{Pd}\left(\mathrm{PPh}_{3}\right)_{4},{ }^{\mathrm{S} 4}, \mathrm{PhI}\left(\mathrm{O}_{2} \mathrm{CCF}_{3}\right)_{2}{ }^{\mathrm{S} 5}$ and $\mathrm{UiO}-67^{\mathrm{S} 7 \mathrm{a}}$ were synthesized following literature procedures. $\mathrm{ZrCl}_{4}$ (Sigma Aldrich), $N$, $N$-dimethylformamide (DMF, 99.9\%, EMD), and glacial acetic acid (Macron) used for synthetic preparations were used as received unless otherwise noted. All other solvents and reagents were purchased from commercial suppliers and used as received. Routine powder X-ray diffraction patterns for phase identification were collected on a Rigaku Miniflex 600 diffractometer using Nickel-filtered $\mathrm{Cu}-\mathrm{K}_{\alpha}$ radiation $(\lambda=$ $1.5418 \AA$ A). High-resolution synchrotron powder diffraction data (PXRD) were collected at $295 \mathrm{~K}$ using beamline 11-BM at the Advanced Photon Source (APS, Argonne National Laboratory, Argonne, IL) using an average wavelength of $0.413959 \AA . \mathrm{N}_{2}$ adsorption isotherms were measured at 77K (liquid nitrogen bath) using a Micromeritics 3Flex Surface Characterization Analyzer. Prior to analysis, samples (100-200 mg) were heated under vacuum until the outgas rate was less than $2 \mathrm{mTorr} / \mathrm{minute}$. ATR-IR spectra were measured using a Nicolet IR 200 with a diamond source. Inductively coupled plasma atomic emission spectroscopy (ICP-AES) measurements were performed using a Perkin Elmer (Optima 8000) instrument and were calibrated using atomic spectroscopy standards purchased from BDH. Elemental microanalyses were performed by Atlantic Microlab, Norcross, GA. ESI-MS experiments were performed at the University of Illinois Mass Spectrometry Laboratory.

Solution-state NMR spectra were measured using either a Varian Inova or MR $400 \mathrm{MHz}$ spectrometer $\left(101 \mathrm{MHz}\right.$ operating frequency for ${ }^{13} \mathrm{C}, 162 \mathrm{MHz}$ operating frequency for ${ }^{31} \mathrm{P}$, and $376 \mathrm{MHz}$ operating frequency for ${ }^{19} \mathrm{~F}$ ). For ${ }^{1} \mathrm{H}$ and ${ }^{13} \mathrm{C}\left\{{ }^{1} \mathrm{H}\right\}$ NMR spectra, the solvent resonance was referenced as an internal standard. For ${ }^{31} \mathrm{P}\left\{{ }^{1} \mathrm{H}\right\}$ NMR spectra, $85 \% \mathrm{H}_{3} \mathrm{PO}_{4}$ was used as an external standard $(0 \mathrm{ppm})$. For ${ }^{19} \mathrm{~F}$ NMR spectra, $1 \% \mathrm{CF}_{3} \mathrm{COOH}$ was used as an external standard (-76.55 ppm). Solid-State NMR experiments were performed on a Bruker (Billerica, MA) DSX-400 spectrometer at a resonance frequency of $400 \mathrm{MHz}$ for ${ }^{1} \mathrm{H}$ and $162 \mathrm{MHz}$ for ${ }^{31} \mathrm{P}$ and $100 \mathrm{MHz}$ for ${ }^{13} \mathrm{C}$, using magic-angle spinning (MAS) probe in double-resonance mode. Samples were packed into $4 \mathrm{~mm}$ rotors with Kel-F $22 \mu \mathrm{L}$ inserts. Experiments were carried out at a spinning frequency of $14 \mathrm{kHz}$. Typical ${ }^{31} \mathrm{P}$ and ${ }^{1} \mathrm{H} 90^{\circ}$ pulse-lengths were $4 \mu \mathrm{s}$ and $6 \mu \mathrm{s}$, respectively. ${ }^{13} \mathrm{C} 90^{\circ}$ pulse-lengths were $4.2 \mu \mathrm{s} .{ }^{31} \mathrm{P}\left[{ }^{1} \mathrm{H}\right] \mathrm{CP} / \mathrm{MAS}$ spectra were obtained with a recycle delay of 2-4 s and two-pulse phase modulation (TPPM) decoupling. Background-free ${ }^{1} \mathrm{H}$ 
spectra were obtained using a subtraction scheme. ${ }^{\mathrm{S} 6}{ }^{13} \mathrm{C}\left[{ }^{1} \mathrm{H}\right]$ composite-pulse multiCP/ MAS spectra had a recycle delay of 2s, 10 loops of $\mathrm{CP}$, and a $200 \mathrm{~ms}{ }^{1} \mathrm{H}$ magnetization recovery delay between $\mathrm{CP}$ periods. The first $9 \mathrm{CP}$ contact-times were $1.1 \mathrm{~ms}$ and the last was $0.6 \mathrm{~ms}$, with 83$100 \%$ linear-ramps on ${ }^{1} \mathrm{H} .{ }^{31} \mathrm{P}$ and ${ }^{1} \mathrm{H}$ spectra were externally referenced to the upfield resonance of calcium hydroxyapatite (National Institute of Standards and Technology) at $2.73 \mathrm{ppm}$ and $0.18 \mathrm{ppm}$, respectively; this corresponds to the $85 \%$ phosphoric acid scale for ${ }^{31} \mathrm{P}$ and to the neat TMS scale for ${ }^{1} \mathrm{H} .{ }^{13} \mathrm{C}$ spectra were external referenced to the carbonyl of $1-{ }^{13} \mathrm{C}$ Gly ( $\beta$ crystal form) at $176.49 \mathrm{ppm}$ on the neat TMS scale. 


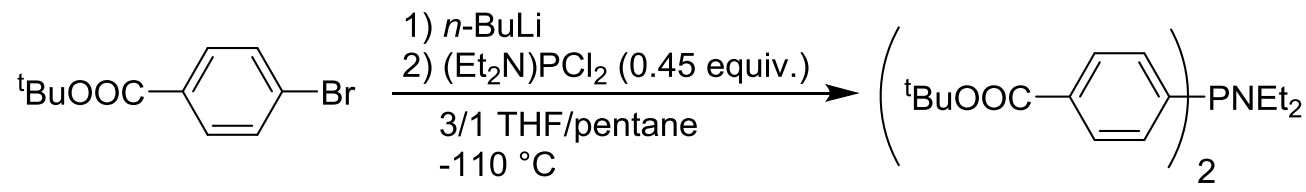

Synthesis of diethylamino bis(tert-butyl 4-benzoyl)phosphine $\left[\mathrm{Et}_{2} \mathrm{NP}\left(\mathrm{C}_{6} \mathrm{H}_{5}-\mathrm{COO}^{t} \mathrm{Bu}\right)_{2}\right]$. A $500 \mathrm{~mL}$ Schlenk flask was charged with 4-bromobenzoic acid tert-butyl ester (5.91 g, $23.0 \mathrm{mmol})$ under an $\mathrm{N}_{2}$ atmosphere. The oil was dissolved in a mixture of THF (90 mL) and pentane (30 $\mathrm{mL}$ ). The reaction vessel was cooled to $-110{ }^{\circ} \mathrm{C}$ in a liquid $\mathrm{N}_{2}$ /ethanol bath. ${ }^{\mathrm{n}} \mathrm{BuLi}$ (10 mL, 2.2 $\mathrm{M}$ in hexane) was added dropwise over 20 minutes. The reaction solution changed from colorless to brown upon completion of the addition. The mixture was allowed to stir at $-110{ }^{\circ} \mathrm{C}$ for 20 minutes. A solution of $\left(\mathrm{NEt}_{2}\right) \mathrm{PCl}_{2}(1.78 \mathrm{~g}, 10.2 \mathrm{mmol})$ in THF $(10 \mathrm{~mL})$ was added dropwise over 10 minutes, keeping the reaction mixture at $-110{ }^{\circ} \mathrm{C}$. The reaction solution changed from brown to yellow upon completion of the addition. The reaction was allowed to warm to room temperature and stirred overnight. The solvent was removed in vacuo, and the residue was extracted with pentane $(\sim 250 \mathrm{~mL})$ and filtered through Celite. The solvent was removed from the filtrate in vacuo to yield a low-density pale yellow solid. The solid was dissolved in a minimum amount of pentane $(\sim 5-10 \mathrm{~mL})$ and transferred to a $20 \mathrm{~mL}$ scintillation vial. Upon standing ( $\sim 5$ minutes), an off-white solid began to precipitate. The vial was placed in a freezer $\left(-30{ }^{\circ} \mathrm{C}\right)$ for $\sim 12 \mathrm{~h}$ to allow for maximum precipitation. The vial was centrifuged and the supernatant was decanted. The remaining solid was dried under vacuum to give clean $\mathrm{Et}_{2} \mathrm{NP}\left(\mathrm{C}_{6} \mathrm{H}_{5}-\mathrm{COO}^{\mathrm{t}} \mathrm{Bu}\right)_{2}(3.4 \mathrm{~g}, 72 \%) .{ }^{1} \mathrm{H} \mathrm{NMR}\left(400 \mathrm{MHz}, \mathrm{CDCl}_{3}\right) \delta 7.95\left(\mathrm{~d},{ }^{3} J_{\mathrm{H}-\mathrm{H}}=8.1 \mathrm{~Hz}, 4 \mathrm{H}\right.$, $\mathrm{Ar}), 7.43\left(\mathrm{t},{ }^{3} J_{\mathrm{H}-\mathrm{H}}=7.3 \mathrm{~Hz}, 4 \mathrm{H}, \mathrm{Ar}\right), 3.07\left(\mathrm{dt},{ }^{3} J_{\mathrm{C}-\mathrm{P}}=16.4,{ }^{3} J_{\mathrm{H}-\mathrm{H}}=7.0 \mathrm{~Hz}, 4 \mathrm{H}, \mathrm{CH}_{2} \mathrm{CH}_{3}\right), 1.59(\mathrm{~s}$, $\left.18 \mathrm{H},{ }^{\mathrm{t}} \mathrm{Bu}\right), 0.95\left(\mathrm{t},{ }^{3} \mathrm{~J}_{\mathrm{H}-\mathrm{H}}=7.0 \mathrm{~Hz}, 6 \mathrm{H}, \mathrm{CH}_{2} \mathrm{CH}_{3}\right) .{ }^{13} \mathrm{C}\left\{{ }^{1} \mathrm{H}\right\} \mathrm{NMR}\left(101 \mathrm{MHz}, \mathrm{CDCl}_{3}\right) \delta 165.70(\mathrm{~s}$, 2C, CO), 145.28 (d, ${ }^{1} J_{\mathrm{C}-\mathrm{P}}=16.9 \mathrm{~Hz}, 2 \mathrm{C}$, ipso $\left.\mathrm{Ph} 1\right), 131.91$ (s, 2C, ipso $\left.\mathrm{Ph} 4\right), 131.73\left(\mathrm{~d},{ }^{2} J_{\mathrm{C}-\mathrm{P}}=\right.$ $19.9 \mathrm{~Hz}, 4 \mathrm{C}, \mathrm{Ph}), 129.11\left(\mathrm{~d},{ }^{3} J_{\mathrm{C}-\mathrm{P}}=5.8 \mathrm{~Hz}, 4 \mathrm{C}, \mathrm{Ph}\right), 81.21\left(\mathrm{~s}, 2 \mathrm{C}, C\left(\mathrm{CH}_{3}\right)_{3}\right), 44.57\left(\mathrm{~d},{ }^{2} J_{\mathrm{C}-\mathrm{P}}=\right.$ $\left.15.4 \mathrm{~Hz}, 2 \mathrm{C}, \mathrm{CH}_{2} \mathrm{CH}_{3}\right), 28.29\left(\mathrm{~s}, 18 \mathrm{C}, \mathrm{C}\left(\mathrm{CH}_{3}\right)_{3}\right), 14.58\left(\mathrm{~d},{ }^{3} J_{\mathrm{C}-\mathrm{P}}=3.0 \mathrm{~Hz}, \mathrm{CH}_{2} \mathrm{CH}_{3}\right) .{ }^{31} \mathrm{P}\left\{{ }^{1} \mathrm{H}\right\}$ NMR (162 MHz, $\left.\mathrm{CDCl}_{3}\right) \delta 60.93(\mathrm{~s}, 1 \mathrm{P})$. 


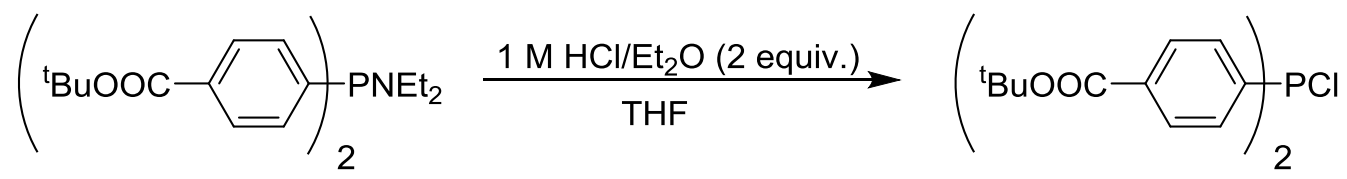

Synthesis of chloro bis(tert-butyl 4-benzoyl)phosphine $\left[\mathrm{CIP}\left(\mathrm{C}_{6} \mathrm{H}_{5}-\mathrm{COO}^{\mathrm{t}} \mathrm{Bu}_{2}\right] . \mathrm{HCl}\right.$ in $\mathrm{Et}_{2} \mathrm{O}$ $(1.0 \mathrm{M}, 13.4 \mathrm{~mL}, 13.4 \mathrm{mmol})$ was added dropwise to a solution of $\mathrm{Et}_{2} \mathrm{NP}\left(\mathrm{C}_{6} \mathrm{H}_{5}-\mathrm{COO}^{t} \mathrm{Bu}\right)_{2}(3.00$ $\mathrm{g}, 6.56 \mathrm{mmol})$ in THF $(\sim 30 \mathrm{~mL})$. Immediate formation of $\left[\mathrm{Et}_{2} \mathrm{NH}_{2}\right] \mathrm{Cl}$ was observed, and the reaction was allowed to stir at room temperature for $1 \mathrm{~h}$. The supernatant solution was separated using a filter cannula, and the solvent was removed in vacuo. The residue was extracted with pentane and filtered through a pad of Celite. The solvent was removed in vacuo to afford a white sticky, low density solid (2.56 g, 93\%). ${ }^{1} \mathrm{H} \mathrm{NMR}\left(400 \mathrm{MHz}, \mathrm{CDCl}_{3}\right) \delta 7.98\left(\mathrm{~d},{ }^{3} J_{\mathrm{H}-\mathrm{H}}=8.1 \mathrm{~Hz}\right.$, $4 \mathrm{H}, \operatorname{Ar} 3), 7.58\left(\mathrm{t},{ }^{3} \mathrm{~J}_{\mathrm{H}-\mathrm{H}}=7.7 \mathrm{~Hz}, 4 \mathrm{H}, \mathrm{Ar} 2\right), 1.56\left(\mathrm{~s}, 18 \mathrm{H},{ }^{\mathrm{t}} \mathrm{Bu}\right) .{ }^{13} \mathrm{C}\left\{{ }^{1} \mathrm{H}\right\} \mathrm{NMR}(101 \mathrm{MHz}$, $\left.\mathrm{CDCl}_{3}\right) \delta 165.05$ (s, 2C, CO), $143.29\left(\mathrm{~d},{ }^{1} J_{\mathrm{C}-\mathrm{P}}=34.4 \mathrm{~Hz}, 2 \mathrm{C}\right.$, ipso Ph 1), 133.88 (s, 2C, ipso Ph 4), $131.50\left(\mathrm{~d},{ }^{2} J_{\mathrm{C}-\mathrm{P}}=24.3 \mathrm{~Hz}, 4 \mathrm{C}, \mathrm{Ph}\right), 129.59\left(\mathrm{~d},{ }^{3} J_{\mathrm{C}-\mathrm{P}}=6.9 \mathrm{~Hz}, 4 \mathrm{C}, \mathrm{Ph}\right), 81.68(\mathrm{~s}, 2 \mathrm{C}$, $\left.C\left(\mathrm{CH}_{3}\right)_{3}\right), 28.24\left(\mathrm{~s}, 18 \mathrm{C}, \mathrm{C}\left(\mathrm{CH}_{3}\right)_{3}\right) .{ }^{31} \mathrm{P}\left\{{ }^{1} \mathrm{H}\right\} \mathrm{NMR}\left(162 \mathrm{MHz}, \mathrm{CDCl}_{3}\right) \delta 77.86(\mathrm{~s}, 1 \mathrm{P})$. 


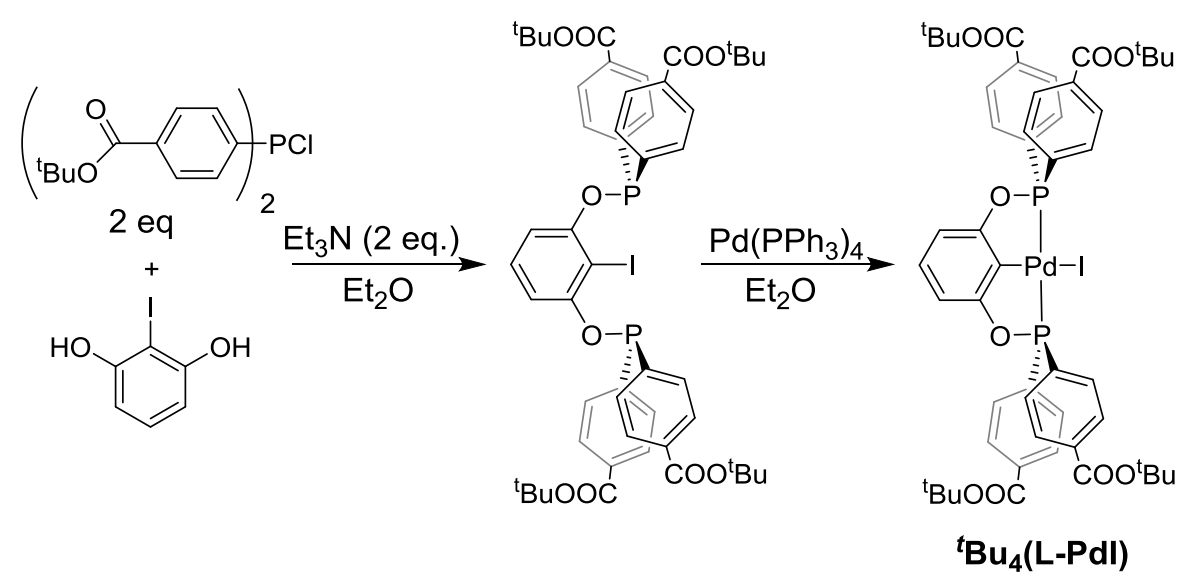

Synthesis of ${ }^{\mathrm{t}} \mathrm{Bu}_{4}(\mathbf{L}-\mathbf{P d I})$. $\mathrm{ClP}\left(\mathrm{C}_{6} \mathrm{H}_{5}-\mathrm{COO}^{\mathrm{t}} \mathrm{Bu}\right)_{2}(1.52 \mathrm{~g}, 3.61 \mathrm{mmol})$ was dissolved in $\mathrm{Et}_{2} \mathrm{O}(\sim 10$ $\mathrm{mL}) . \mathrm{NEt}_{3}(0.53 \mathrm{~mL}, 3.8 \mathrm{mmol})$ was added, and the solution was allowed to stir at room temperature for 10 minutes. A solution of 2-iodo resorcinol $(0.405 \mathrm{~g}, 1.72 \mathrm{mmol})$ in $^{2} \mathrm{Et}_{2} \mathrm{O}(\sim 5$ $\mathrm{mL}$ ) was added dropwise resulting in precipitation of $\left[\mathrm{HNEt}_{3}\right] \mathrm{Cl}$. The reaction mixture was allowed to stir at room temperature for $2 \mathrm{~h}$ before filtering through a pad of Celite to remove $\left[\mathrm{HNEt}_{3}\right] \mathrm{Cl}$. The resulting solution of the POCOP-I ligand was characterized in situ by ${ }^{31} \mathrm{P}\left\{{ }^{1} \mathrm{H}\right\}$ NMR spectroscopy $(\delta=110 \mathrm{ppm})$ and used without further purification. $\mathrm{The}_{2} \mathrm{Et}_{2} \mathrm{O}$ solution of POCOP-I was added to a suspension of $\mathrm{Pd}\left(\mathrm{PPh}_{3}\right)_{4}(1.69 \mathrm{~g}, 1.46 \mathrm{mmol})$ in $\mathrm{Et}_{2} \mathrm{O}(\sim 25 \mathrm{~mL})$, and the reaction mixture was stirred overnight at room temperature. The resulting yellow solution was filtered through Celite, and the filtrate was concentrated on a rotary evaporator. The oily residue was dissolved in minimal DCM, loaded onto a silica gel chromatography column packed with hexanes, and flash chromatographed using 9:1 hexanes:ethyl acetate as the eluent. The desired product was obtained as a bright yellow low-density solid (1.37 g, 72\% yield). Product obtained from fractions that contain $\mathrm{PPh}_{3}$ as a minor impurity can be recrystallized from MeCN. ${ }^{1} \mathrm{H}$ NMR $\left(400 \mathrm{MHz}, \mathrm{CDCl}_{3}\right) \delta 8.12-7.99\left(\mathrm{~m}, 16 \mathrm{H}\right.$, benzoate Ar-H), $7.18\left(\mathrm{t},{ }^{3} J_{\mathrm{H}-\mathrm{H}}=7.8 \mathrm{~Hz}, 1 \mathrm{H}\right.$, resorcinol Ar-H), $6.85\left(\mathrm{~d},{ }^{3} J_{\mathrm{H}-\mathrm{H}}=7.9 \mathrm{~Hz}, 2 \mathrm{H}\right.$, resorcinol Ar-H), $1.57\left(\mathrm{~s}, 36 \mathrm{H},{ }^{\mathrm{t}} \mathrm{Bu}\right) .{ }^{13} \mathrm{C}\left\{{ }^{1} \mathrm{H}\right\}$ NMR (101 MHz, CDCl $\left.{ }_{3}\right) \delta 164.78(\mathrm{~s}, 4 \mathrm{C}, \mathrm{CO}), 163.99$ (t, $\left.J_{\mathrm{C}-\mathrm{P}}=7.8 \mathrm{~Hz}, \mathrm{Ar}\right), 138.02(\mathrm{~s}, \mathrm{Ar})$, $136.88\left(\mathrm{t}, J_{\mathrm{C}-\mathrm{P}}=25.7 \mathrm{~Hz}, \mathrm{Ar}\right), 135.47(\mathrm{~s}, \mathrm{Ar}), 132.19\left(\mathrm{t}, J_{\mathrm{C}-\mathrm{P}}=8.1 \mathrm{~Hz}, \mathrm{Ar}\right), 129.81\left(\mathrm{t}, J_{\mathrm{C}-\mathrm{P}}=5.6\right.$ $\mathrm{Hz}, \mathrm{Ar}), 129.59$ (s, Ar), 107.61 (t, $\left.J_{\mathrm{C}-\mathrm{P}}=8.1 \mathrm{~Hz}, \mathrm{Ar}\right), 81.97\left(\mathrm{~s}, 4 \mathrm{C}, C\left(\mathrm{CH}_{3}\right)_{3}\right), 28.51$ (s, 36C, $\left.\mathrm{C}\left(\mathrm{CH}_{3}\right)_{3}\right) .{ }^{31} \mathrm{P}\left\{{ }^{1} \mathrm{H}\right\}$ NMR $\left(162 \mathrm{MHz}, \mathrm{CDCl}_{3}\right) \delta 148.37$ (s, 2P). Anal. Calcd. for $\mathrm{C}_{50} \mathrm{H}_{55} \mathrm{IO}_{10} \mathrm{P}_{2} \mathrm{Pd}$ : C, 54.04; H, 4.99. Found: C, 54.24; H, 5.08 . 


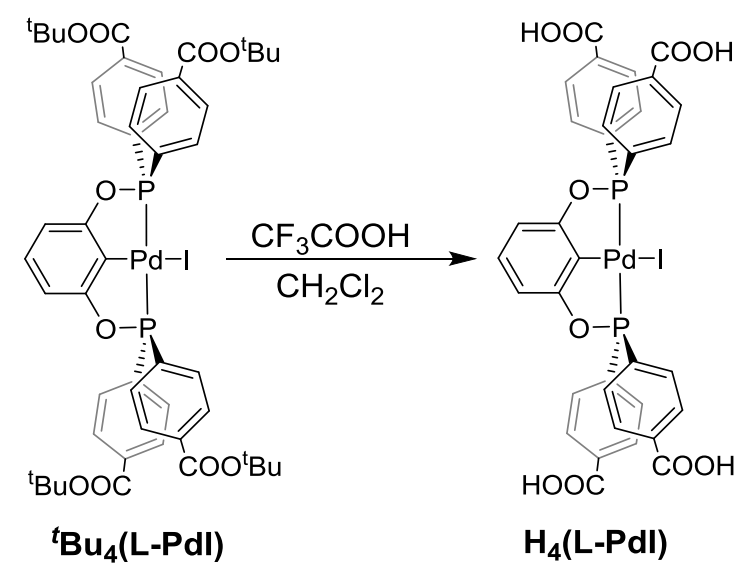

Synthesis of $\mathbf{H}_{4}(\mathbf{L}-\mathbf{P d I})$. Trifluoroacetic acid $(1 \mathrm{~mL})$ was added to a solution of ${ }^{\mathrm{t}} \mathrm{Bu}_{4}(\mathrm{~L}-\mathrm{PdI})$ $(1.03 \mathrm{~g}, 0.929 \mathrm{mmol})$ in DCM (3 mL) resulting in a color change of the solution from yellow to dark purple. The solution was stirred for $12 \mathrm{~h}$ at room temperature before removing the solvent using a rotary evaporator. DI water was added resulting in precipitation of a dark yellow solid. The solid was collected by vacuum filtration and washed with DI water $(3 \times 5 \mathrm{~mL})$ and $\mathrm{CHCl}_{3}$ ( $\sim 15 \mathrm{~mL})$ until a bright yellow was obtained. The solid was dried under vacuum to afford $\mathrm{H}_{4}(\mathrm{~L}-$ PdI) $\left(0.778 \mathrm{~g}, 94 \%\right.$ yield). ${ }^{1} \mathrm{H}$ NMR (400 MHz, DMSO- $\left.d_{6}\right) \delta 14.24(\mathrm{~s}, 4 \mathrm{H}, \mathrm{COOH}), 8.98\left(\mathrm{~d},{ }^{3} J_{\mathrm{H}-\mathrm{H}}\right.$ $=7.9 \mathrm{~Hz}, 8 \mathrm{H}$, benzoate Ar-H), $8.92-8.83(\mathrm{~m}, 8 \mathrm{H}$, benzoate $\mathrm{Ar}-\mathrm{H}), 8.10\left(\mathrm{t},{ }^{3} J_{\mathrm{H}-\mathrm{H}}=8.1 \mathrm{~Hz}, 1 \mathrm{H}\right.$, resorcinol Ar-H), $7.79\left(\mathrm{~d},{ }^{3} J_{\mathrm{H}-\mathrm{H}}=8.0 \mathrm{~Hz}, 2 \mathrm{H}\right.$ resorcinol Ar-H). ${ }^{13} \mathrm{C}\left\{{ }^{1} \mathrm{H}\right\}$ NMR (101 MHz, DMSO- $\left.d_{6}\right) \delta 166.40(\mathrm{~s}, 4 \mathrm{C}, \mathrm{CO}), 163.30\left(\mathrm{t}, J_{\mathrm{C}-\mathrm{P}}=7.3 \mathrm{~Hz}, \mathrm{Ar}\right), 136.98(\mathrm{~s}, \mathrm{Ar}), 136.02\left(\mathrm{t}, J_{\mathrm{C}-\mathrm{P}}=\right.$ $25.3 \mathrm{~Hz}, \mathrm{Ar}$ ), 134.64 (s, Ar), 132.13 (t, $\left.J_{\mathrm{C}-\mathrm{P}}=7.9 \mathrm{~Hz}, \mathrm{Ar}\right), 130.22$ (s, Ar), 130.00 (t, $J_{\mathrm{C}-\mathrm{P}}=5.3 \mathrm{~Hz}$, Ar), 107.77 (t, $\left.J_{\mathrm{C}-\mathrm{P}}=8.8 \mathrm{~Hz}, \mathrm{Ar}\right) .{ }^{31} \mathrm{P}\left\{{ }^{1} \mathrm{H}\right\}$ NMR $\left(162 \mathrm{MHz}, \mathrm{DMSO}-d_{6}\right) \delta 149.22(\mathrm{~s}, 2 \mathrm{P})$. Anal. Calcd. for $\mathrm{C}_{34} \mathrm{H}_{23} \mathrm{IO}_{10} \mathrm{P}_{2} \mathrm{Pd}$ : C, 45.13; H, 2.79. Found: C, 46.96; H, 2.94. One $\mathrm{H}_{2} \mathrm{O}$ molecule is associated with the compound presumably via a hydrogen bonding interaction with the carboxylic acids. 
Solvothermal synthesis of 1-X. Solutions of anhydrous $\mathrm{ZrCl}_{4}(0.256 \mathrm{~g}, 1.10 \mathrm{mmol})$ in DMF (36 $\mathrm{mL})$ and $\mathrm{H}_{4}(\mathrm{~L}-\mathrm{PdI})(0.360 \mathrm{~g}, 0.405 \mathrm{mmol})$ in DMF $(36 \mathrm{~mL})$ were sonicated for 5 minutes to ensure complete dissolution of the solids. $6 \mathrm{~mL}$ of each solution was added to each of six $20 \mathrm{~mL}$ screw-top scintillation vials. Glacial acetic acid $(3 \mathrm{~mL})$ was then added to each vial. The vials were sealed with Teflon-lined screw-top caps (Qorpak ${ }^{\circledR}$ CAP-00554), placed in a programmable oven at room temperature, and heated to $120{ }^{\circ} \mathrm{C}$ for $12 \mathrm{~h}$. After cooling to room temperature, a light grey solid had settled on the bottom of the vials. The solvent was decanted and the solids were combined and washed with DMF $(3 \mathrm{x} \sim 18 \mathrm{~mL})$ and acetone $(1 \mathrm{x} \sim 18 \mathrm{~mL})$. The solid was dried in vacuo ( 0.01 torr) at room temperature for $2 \mathrm{~h}$ before activating under high vacuum $\left(10^{-4}\right.$ torr) at $150{ }^{\circ} \mathrm{C}$ for $12 \mathrm{~h}$. The solid changes from a grey-white to light yellow color upon activation $(0.482 \mathrm{~g}$ before activation, $0.382 \mathrm{~g}$ after activation). Anal. Calcd. for $\mathrm{Zr}_{6} \mathrm{O}_{4}(\mathrm{OH})_{4}\left[\mathrm{PdCl}_{0.4} \mathrm{I}_{0.6} \mathrm{C}_{34} \mathrm{H}_{19} \mathrm{O}_{10} \mathrm{P}_{2}\right]_{3}\left(\mathrm{C}_{3} \mathrm{H}_{7} \mathrm{NO}\right)_{0.8}\left(\mathrm{CH}_{3} \mathrm{COOH}\right)_{1.2} ; \mathrm{C}, 38.74 ; \mathrm{H}, 2.57 ; \mathrm{N}, 0.93 ; \mathrm{I}$, 6.33; Cl, 1.18. Found: C, 35.85; H, 2.32; N, 0.53; I, 6.48; Cl, 1.0 .

Repeated attempts at elemental analysis of 1-X consistently showed residual $\mathrm{N}$ and a lower than expected $\mathrm{C}$ content. ${ }^{1} \mathrm{H}$ NMR analysis of a sample of activated 1-X digested with $\mathrm{CF}_{3} \mathrm{COOH} / \mathrm{dmso} \mathrm{d}_{6}$ confirmed that residual DMF is responsible for the observed $\mathrm{N}$ and also the presence of acetic acid (Figure S14). The amount of DMF and $\mathrm{CH}_{3} \mathrm{COOH}$ present in activated 1$\mathbf{X}$ could not be accurately determined using solution ${ }^{1} \mathrm{H}$ NMR due to incomplete dissolution of the MOF and decomposition of $\mathrm{H}_{4}(\mathrm{~L}-\mathrm{PdX})$ during acid digestion. However, integration of the quantitative solid state MAS ${ }^{13} \mathrm{C} \quad \mathrm{NMR}$ spectrum indicates $\sim 0.8$ DMF and $\sim 1.2$ $\mathrm{CH}_{3} \mathrm{COOH} / \mathrm{CH}_{3} \mathrm{COO}^{-}$molecules per $[\mathrm{L}-\mathrm{PdX}]^{4-}$ linker. Missing-linker defects have been proposed to lower the $\mathrm{C}$ content of other Zr MOFs. ${ }^{\mathrm{S} 7}$ While this may be the cause of the lower than expected $\mathrm{C}$ content for $\mathbf{1 - X}$, it may also be due to the phosphorus-containing impurity indicated by the signal at $93 \mathrm{ppm}$ in the solid state MAS ${ }^{31}$ NMR spectrum. Furthermore, the MAS ${ }^{31} \mathrm{P}$ spectrum of 1-X after activation (Figure S15) shows a small signal at $\sim 30 \mathrm{ppm}$, attributed to partial oxidation/decomposition of the phosphine pincer ligand. ICP-AES analysis of 1-X revealed a higher than expected $\mathrm{Zr} / \mathrm{Pd}$ ratio (2:0.93) consistent with either missing linker defects or partial ligand decomposition. 
Synthesis of 1-TFA. A sample of 1-X $(0.182 \mathrm{~g})$ was suspended in DCM $(5 \mathrm{~mL})$ in a $20 \mathrm{~mL}$ scintillation vial. A solution of PhI(TFA $)_{2}(0.070 \mathrm{~g}, 0.16 \mathrm{mmol})$ in DCM $(5 \mathrm{~mL})$ was added, and the vial was sealed and left gently stirring at room temperature. After $12 \mathrm{~h}$, the reaction mixture was centrifuged and the pink-purple supernatant was decanted. A fresh solution of PhI(TFA) 2 $(0.07 \mathrm{~g}, 0.16 \mathrm{mmol})$ in DCM $(5 \mathrm{~mL})$ was added and the reaction was stirred for another $12 \mathrm{~h}$. The mixture was centrifuged, and the clear colorless supernatant was decanted. The solid was washed with DCM (3 x $10 \mathrm{~mL})$ and soaked in methanol (15 mL) for $12 \mathrm{~h}$. The solvent was decanted and the solid was washed with methanol $(3 \times 10 \mathrm{~mL})$. Samples of 1-TFA were dried under vacuum for $3 \mathrm{~h}$ prior to using for catalysis. For surface area measurements, a sample was activated under high vacuum $\left(10^{-4}\right.$ torr $)$ at $100{ }^{\circ} \mathrm{C}$ for $12 \mathrm{~h}$. The solid remained a silvery grey color upon activation. (0.217 $\mathrm{g}$ before activation, $0.204 \mathrm{~g}$ after activation). Selected $\mathrm{CF}_{3} \mathrm{COOH}$ bands observed in the ATR-IR spectrum of 1-TFA: $1655 \mathrm{~cm}^{-1}$ [asymm. $\left.v(\mathrm{COO})\right], 1199.8 \mathrm{~cm}^{-1}$ [asymm. $v(\mathrm{C}-\mathrm{F})], \quad 1152 \mathrm{~cm}^{-1} \quad$ [asymm. $v(\mathrm{C}-\mathrm{F})$ ]. Anal. Calcd. for $\mathrm{Zr}_{6} \mathrm{O}_{4}(\mathrm{OH})_{4}\left[\mathrm{C}_{34} \mathrm{H}_{19} \mathrm{O}_{10} \mathrm{P}_{2} \mathrm{Pd}\left(\mathrm{CF}_{3} \mathrm{COO}\right)_{0.44} \mathrm{Cl}_{0.39} \mathrm{I}_{0.17}\right]_{3} ; \mathrm{C}, 39.25 ; \mathrm{H}, 1.92 ; \mathrm{N}, 0.0 ; \mathrm{I}, 2.02 ; \mathrm{Cl}, 1.30$; F, 2.35. Found: C, 36.52; H, 1.76; N, 0.0; I, 2.71; Cl, 1.71; F, 3.13.

Similar to 1-X, 1-TFA exhibits a lower than expected C content. Halide analysis (combustion ion chromatography) of 1-TFA shows the presence of I (2.71 wt. \%), Cl (1.71 wt. \%), and F (3.13 wt. \%). Assuming the observed halide content is the result of charge balancing ligands at the Pd sites, $\mathrm{I}^{-}, \mathrm{Cl}^{-}$, and $\mathrm{CF}_{3} \mathrm{COO}^{-}$are present in a 1:2.26:2.57 mole ratio. Normalization gives $0.17 \mathrm{I}^{-}, 0.39 \mathrm{Cl}^{-}$, and $0.44 \mathrm{CF}_{3} \mathrm{COO}^{-}$per $\mathrm{Pd}$. These results suggest that reaction of $\mathbf{1 - X}$ with $\mathrm{PhI}(\mathrm{TFA})_{2}$ facilitates $\mathrm{I}^{-} / \mathrm{CF}_{3} \mathrm{COO}^{-}$ligand exchange in $\sim 72 \%$ yield, but does not result in ligand substitution at the $\mathrm{Pd}-\mathrm{Cl}$ sites. 
Synthesis of ${ }^{t} \mathrm{Bu}_{4}(\mathbf{L}-\mathbf{P d C l}) .{ }^{\mathrm{t}} \mathrm{Bu}_{4}(\mathrm{~L}-\mathrm{PdI})(0.165 \mathrm{~g}, 0.148 \mathrm{mmol})$ was dissolved in THF $(\sim 3 \mathrm{~mL})$ and a solution of $\operatorname{AgOTf}(0.0427 \mathrm{~g}, 0.166 \mathrm{mmol})$ in THF $(\sim 2 \mathrm{~mL})$ was added dropwise, resulting in immediate precipitation of AgI. The reaction was stirred at room temperature for $30 \mathrm{~min}$ before filtering through Celite. A solution of $\mathrm{LiCl}(0.063 \mathrm{~g}, 1.5 \mathrm{mmol})$ in $\mathrm{THF}(\sim 10 \mathrm{~mL})$ was added to the filtrate, and the mixture was stirred at room temperature for $1.5 \mathrm{~h}$ before evaporating to dryness. The residue was extracted with DCM and filtered through Celite. The solvent was removed under vacuum to afford ${ }^{t} \mathrm{Bu}_{4}(\mathrm{~L}-\mathrm{PdCl})$ as an off-white solid $(0.093 \mathrm{~g}, 62 \%$ yield $) .{ }^{1} \mathrm{H}$ NMR $\left(400 \mathrm{MHz}, \mathrm{CDCl}_{3}\right) \delta 8.04\left(\mathrm{~m}, 16 \mathrm{H}\right.$, benzoate Ar-H), $7.15\left(\mathrm{t},{ }^{3} J_{\mathrm{H}-\mathrm{H}}=8.1 \mathrm{~Hz}, 1 \mathrm{H}\right.$, resorcinol Ar-H), $6.82\left(\mathrm{~d},{ }^{3} J_{\mathrm{H}-\mathrm{H}}=8.1 \mathrm{~Hz}, 2 \mathrm{H}\right.$, resorcinol Ar-H), $1.57\left(\mathrm{~s}, 36 \mathrm{H},{ }^{\mathrm{t}} \mathrm{Bu}\right),{ }^{13} \mathrm{C}\left\{{ }^{1} \mathrm{H}\right\} \mathrm{NMR}(101$ $\mathrm{MHz}_{\mathrm{CDCl}}$ ) $\delta 164.79(\mathrm{~s}, 4 \mathrm{C}, \mathrm{CO}), 164.37$ (t, $\left.J_{\mathrm{C}-\mathrm{P}}=8.3 \mathrm{~Hz}, \mathrm{Ar}\right), 137.06\left(\mathrm{t}, J_{\mathrm{C}-\mathrm{P}}=24.7 \mathrm{~Hz}, \mathrm{Ar}\right.$ ), $135.46(\mathrm{~s}, \mathrm{Ar}), 131.34$ (t, $\left.J_{\mathrm{C}-\mathrm{P}}=8.3 \mathrm{~Hz}, \mathrm{Ar}\right), 129.95$ (t, J = 5.7 Hz, Ar), 129.46 (s, Ar), 107.90 (t, $\left.J_{\mathrm{C}-\mathrm{P}}=7.3 \mathrm{~Hz}, \mathrm{Ar}\right), 81.95\left(\mathrm{~s}, 4 \mathrm{C}, \mathrm{C}\left(\mathrm{CH}_{3}\right)_{3}\right), 28.24\left(\mathrm{~s}, 36 \mathrm{C}, \mathrm{C}\left(\mathrm{CH}_{3}\right)_{3}\right)$, one signal missing presumably due to coincidental overlap. ${ }^{31} \mathrm{P}\left\{{ }^{1} \mathrm{H}\right\} \mathrm{NMR}\left(162 \mathrm{MHz}, \mathrm{CDCl}_{3}\right) \delta 142.23$. 


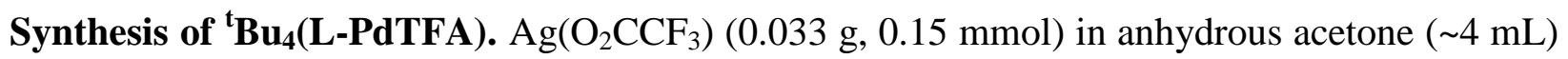
was added dropwise to a solution of ${ }^{t} \mathrm{Bu}_{4}(\mathrm{~L}-\mathrm{PdI})$ in anhydrous acetone $(\sim 6 \mathrm{~mL})$. A white solid precipitate (AgI) was immediately observed upon addition of $\mathrm{Ag}\left(\mathrm{O}_{2} \mathrm{CCF}_{3}\right)$. The reaction mixture was stirred at room temperature for $2 \mathrm{~h}$ before filtering through a frit containing Celite to remove $\mathrm{AgI}$. The filtrate was evaporated to dryness in vacuo to obtain ${ }^{\mathrm{t}} \mathrm{Bu}_{4}(\mathrm{~L}-\mathrm{PdTFA})$ as a white solid (0.143 g, 97\% yield). ${ }^{1} \mathrm{H}$ NMR (400 MHz, $\left.\mathrm{CDCl}_{3}\right) \delta 8.09\left(\mathrm{~d},{ }^{3} \mathrm{~J}_{\mathrm{H}-\mathrm{H}}=7.9 \mathrm{~Hz}, 8 \mathrm{H}\right.$, benzoate Ar-H), $7.89\left(\mathrm{q},{ }^{3} J_{\mathrm{H}-\mathrm{H}}=6.4 \mathrm{~Hz}, 8 \mathrm{H}\right.$, benzoate Ar-H), $7.14\left(\mathrm{t},{ }^{3} J_{\mathrm{H}-\mathrm{H}}=8.1 \mathrm{~Hz}, 1 \mathrm{H}\right.$, resorcinol Ar-H), $6.76\left(\mathrm{~d},{ }^{3} J_{\mathrm{H}-\mathrm{H}}=8.1 \mathrm{~Hz}, 2 \mathrm{H}\right.$, resorcinol Ar-H), $1.59\left(\mathrm{~s}, 36 \mathrm{H},{ }^{\mathrm{t}} \mathrm{Bu}\right) .{ }^{13} \mathrm{C}\left\{{ }^{1} \mathrm{H}\right\} \mathrm{NMR}(101 \mathrm{MHz}$, $\left.\mathrm{CDCl}_{3}\right) \delta 164.76(\mathrm{~s}, 4 \mathrm{C}, \mathrm{CO}), 161.47\left(\mathrm{~d}, J_{\mathrm{C}-\mathrm{P}}=36.0 \mathrm{~Hz}, \mathrm{Ar}\right), 136.93\left(\mathrm{t}, J_{\mathrm{C}-\mathrm{P}}=25.4 \mathrm{~Hz}, \mathrm{Ar}\right)$, $135.60(\mathrm{~s}, \mathrm{Ar}), 131.71$ (t, $\left.J_{\mathrm{C}-\mathrm{P}}=8.3 \mathrm{~Hz}, \mathrm{Ar}\right), 129.86$ (t, $\left.J_{\mathrm{C}-\mathrm{P}}=5.6 \mathrm{~Hz}, \mathrm{Ar}\right), 117.85$ (s, Ar), 114.95 $(\mathrm{s}, \mathrm{Ar}), 107.93\left(\mathrm{t}, J_{\mathrm{C}-\mathrm{P}}=7.7 \mathrm{~Hz}, \mathrm{Ar}\right), 82.02\left(\mathrm{~s}, 4 \mathrm{C}, C\left(\mathrm{CH}_{3}\right)_{3}\right), 28.25\left(\mathrm{~s}, 36 \mathrm{C}, \mathrm{C}\left(\mathrm{CH}_{3}\right)_{3}\right) .{ }^{31} \mathrm{P}\left\{{ }^{1} \mathrm{H}\right\}$ NMR (162 MHz, $\left.\mathrm{CDCl}_{3}\right) \delta 143.85(2 \mathrm{P}) .{ }^{19} \mathrm{~F} \mathrm{NMR}\left(376 \mathrm{MHz}, \mathrm{CDCl}_{3}\right) \delta-74.82$. 

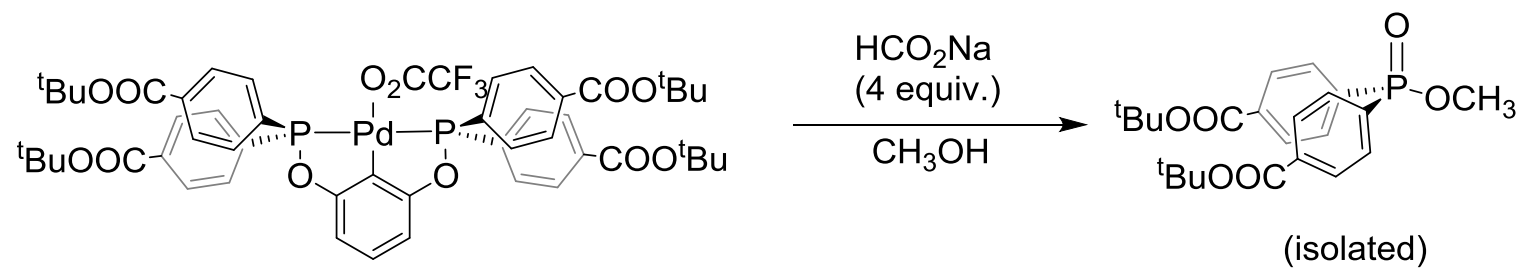

Reaction of ${ }^{\mathrm{t}} \mathbf{B u}_{4}(\mathbf{L}$-PdTFA $)$ with $\mathbf{H C O}_{2} \mathbf{N a}$. Solid $\mathrm{HCO}_{2} \mathrm{Na}(0.016 \mathrm{~g}, 0.23 \mathrm{mmol})$ was added to a solution of ${ }^{\mathbf{t}} \mathbf{B u}_{4}(\mathbf{L}-\mathbf{P d T F A})(0.060 \mathrm{~g}, 0.055 \mathrm{mmol})$ in $\mathrm{CD}_{3} \mathrm{OD}(3 \mathrm{~mL})$. The ${ }^{31} \mathrm{P}\left\{{ }^{1} \mathrm{H}\right\} \mathrm{NMR}$ spectrum measured immediately after adding $\mathrm{HCO}_{2} \mathrm{Na}$ showed a single resonance corresponding to ${ }^{\mathrm{t}} \mathbf{B u}_{4}(\mathbf{L}-\mathbf{P d T F A})$ at $144 \mathrm{ppm}$. After stirring for $12 \mathrm{~h}$, the starting material resonance had completely disappeared and was replaced by a new signal at $33.8 \mathrm{ppm}$. The solvent was removed under vacuum and the phosphorus-containing product was isolated by flash chromatography on silica using 9:1 hexanes:ethyl acetate as the eluent. The ${ }^{31} \mathrm{P}\left\{{ }^{1} \mathrm{H}\right\}$ NMR resonance of the isolated product matched that observed in situ, and the dominant resonances in the ${ }^{1} \mathrm{H}$ NMR spectrum could be assigned to tert-butyl benzoate groups (Figure S11). The ESI mass spectrum of the isolated product showed a major peak at $\mathrm{m} / \mathrm{z}=436.2$ which corresponds to $\left.\left[{ }^{t} \mathrm{BuO}_{2} \mathrm{CPh}\right)_{2} \mathrm{P}(\mathrm{O}) \mathrm{OCD}_{3}+\mathrm{H}\right]^{+}$(Figure S12). When the reaction was repeated using $\mathrm{CH}_{3} \mathrm{OH}$ as the solvent, the ${ }^{1} \mathrm{H}$ NMR spectrum of the isolated product displayed a doublet at $3.79 \mathrm{ppm}$, confirming the presence of the phosphinate methyl ester (Figure S13). NMR data for product isolated from reaction with $\mathrm{CH}_{3} \mathrm{OH}$ as the solvent: ${ }^{1} \mathrm{H} \mathrm{NMR}\left(400 \mathrm{MHz}, \mathrm{CDCl}_{3}\right) \delta 8.06\left(\mathrm{dd},{ }^{3} J_{\mathrm{H}-\mathrm{H}}\right.$ $=7.81 \mathrm{~Hz},{ }^{4} J_{\mathrm{H}-\mathrm{P}}=3.13 \mathrm{~Hz}, 4 \mathrm{H}$, benzoate Ar-H), $7.85\left(\mathrm{dd},{ }^{3} J_{\mathrm{H}-\mathrm{H}}=7.81 \mathrm{~Hz},{ }^{3} J_{\mathrm{H}-\mathrm{P}}=11.77 \mathrm{~Hz}, 4 \mathrm{H}\right.$, benzoate Ar-H), $3.79\left(\mathrm{~d},{ }^{3} \mathrm{~J}_{\mathrm{H}-\mathrm{P}}=10.93 \mathrm{~Hz}, 3 \mathrm{H}, \mathrm{P}-\mathrm{OCH}_{3}\right), 1.59\left(\mathrm{~s}, 18 \mathrm{H}, \mathrm{C}(\mathrm{O}) \mathrm{O}-\mathrm{C}\left(\mathrm{CH}_{3}\right)_{3}\right)$. ${ }^{31} \mathrm{P}\left\{{ }^{1} \mathrm{H}\right\}$ NMR $\left(162 \mathrm{MHz}, \mathrm{CDCl}_{3}\right) \delta 31.03$. 
General procedure for catalytic hydrogenation of aldehydes. A 1 dram vial was charged with catalyst $(0.01 \mathrm{mmol}$ based on $\mathrm{Pd})$, sodium formate $(0.2 \mathrm{mmol}), \mathrm{MeOH}(1 \mathrm{~mL}), \mathrm{H}_{2} \mathrm{O}(1 \mathrm{~mL})$, formic acid $(0.6 \mathrm{mmol})$ and the desired aldehyde $(0.2 \mathrm{mmol})$. The vial was sealed with a Teflonlined screw cap and stirred gently $(100 \mathrm{rpm})$ at $60{ }^{\circ} \mathrm{C}$ for $12 \mathrm{~h}$. Upon cooling, the reaction mixture was extracted with $\mathrm{CDCl}_{3}(1.2 \mathrm{~mL})$ and 1,3,5-trimethoxybenzene $(1 \mathrm{mmol})$ was added to the separated $\mathrm{CDCl}_{3}$ solution as an internal standard. The alcohol products were identified and quantified by ${ }^{1} \mathrm{H}$ NMR spectroscopy. All runs were carried out in triplicate and the conversions and yields given in Table 1 are an average of 3 runs. Representative ${ }^{1} \mathrm{H}$ NMR spectra of products of entries 1-2, 5-6, and 9 from Table are shown in Figures S16-S20. Representative ${ }^{1} \mathrm{H}$ NMR spectra of products of entries 1-10 from Table S1 are shown in Figures S23-S32.

Hot filtration test. A $20 \mathrm{~mL}$ vial was charged with 1-TFA (0.02 mmol based on Pd), sodium formate $(0.4 \mathrm{mmol}), \mathrm{MeOH}(2 \mathrm{~mL}), \mathrm{H}_{2} \mathrm{O}(2 \mathrm{~mL})$, formic acid $(1.2 \mathrm{mmol})$, benzaldehyde $(0.4$ mmol) and 1,3,5-trimethoxybenzene $(0.2 \mathrm{mmol})$. The vial was sealed with a Teflon lined screw cap and stirred gently at $60^{\circ} \mathrm{C}$. After $3 \mathrm{~h}$, the catalyst was removed by filtration, and half of the filtrate (aliquot A) was extracted with $\mathrm{CDCl}_{3}(1.2 \mathrm{~mL})$ and immediately analyzed by ${ }^{1} \mathrm{H} \mathrm{NMR}$ spectroscopy. The remainder of the filtrate (aliquot B) was transferred to a 1 dram vial, sealed, and heated at $60{ }^{\circ} \mathrm{C}$. After $13 \mathrm{~h}$, the aliquot B was cooled to room temperature, extracted with $\mathrm{CDCl}_{3}(1.2 \mathrm{~mL})$, and analyzed by ${ }^{1} \mathrm{H}$ NMR. The ${ }^{1} \mathrm{H}$ NMR spectra showed $27 \%$ and $30 \%$ yield (28\% and $20 \%$ conversion) of benzaldehyde for aliquot A and B, respectively (Figures S21 and S22). 
Table S1. Catalytic Transfer Hydrogenation of Aldehydes with 1-TFA

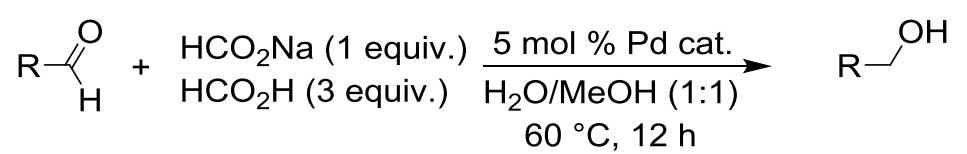

Entry

${ }^{a}$ Reaction conditions: substrate $(0.2 \mathrm{mmol})$, catalyst $(0.01 \mathrm{mmol})$, sodium formate $(0.2 \mathrm{mmol})$, formic acid $(0.6 \mathrm{mmol})$ in $1: 1 \mathrm{H}_{2} \mathrm{O} / \mathrm{MeOH}(2 \mathrm{~mL}), 12 \mathrm{~h}, 60{ }^{\circ} \mathrm{C}$. ${ }^{b}$ Based on conversion to benzylic alcohol. ${ }^{c}$ Determined by ${ }^{1} \mathrm{H}$ NMR with internal standard (1,3,5-trimethoxybenzene) after work up. 
a)

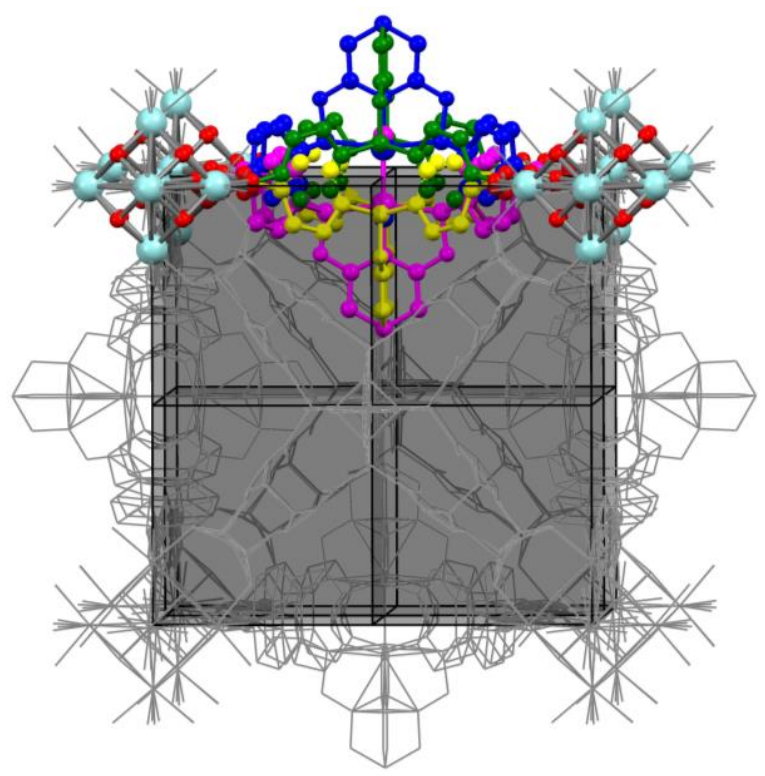

b)

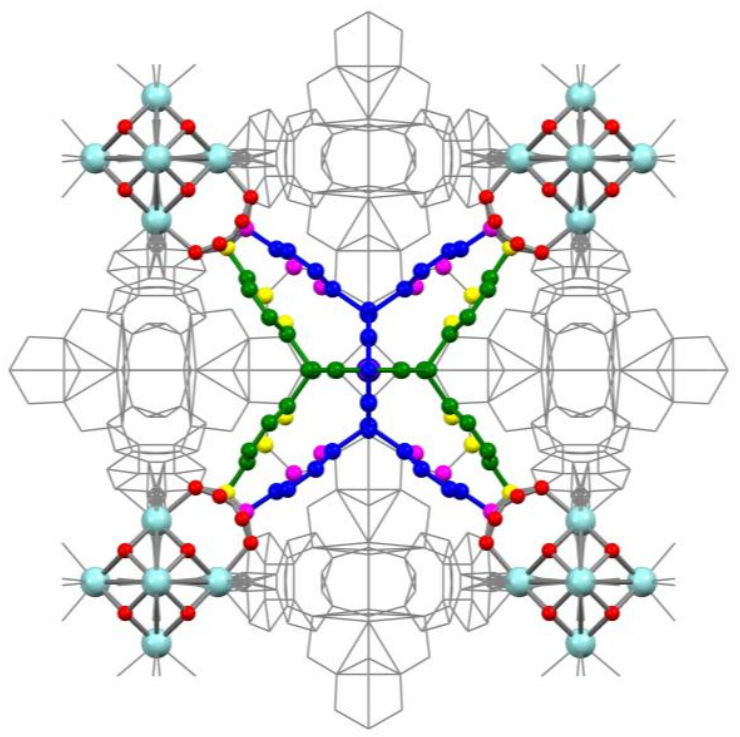

Figure S1. Structures of 1-X showing four-fold disorder of the $[\mathrm{L}-\mathrm{PdX}]^{4-}$ linkers. a) View of the structure of 1-X emphasizing the crystallographic disorder. Crystallographic mirror planes normal to the cell axes (shaded in dark gray) result in disorder between the linker positions shown in blue/green and those shown in magenta/yellow. b) View of the structure of 1-X emphasizing the non-crystallographic disorder. The $\mathrm{C}_{2 \mathrm{v}}$ molecular symmetry of the linkers gives rise to non-crystallographic rotational disorder. The linkers symmetrically span each face of the cubic cell offering the possibility of two different orientations related by a $90^{\circ}$ rotation. This results in disorder between the linker orientations shown in blue/magenta and green/yellow. 


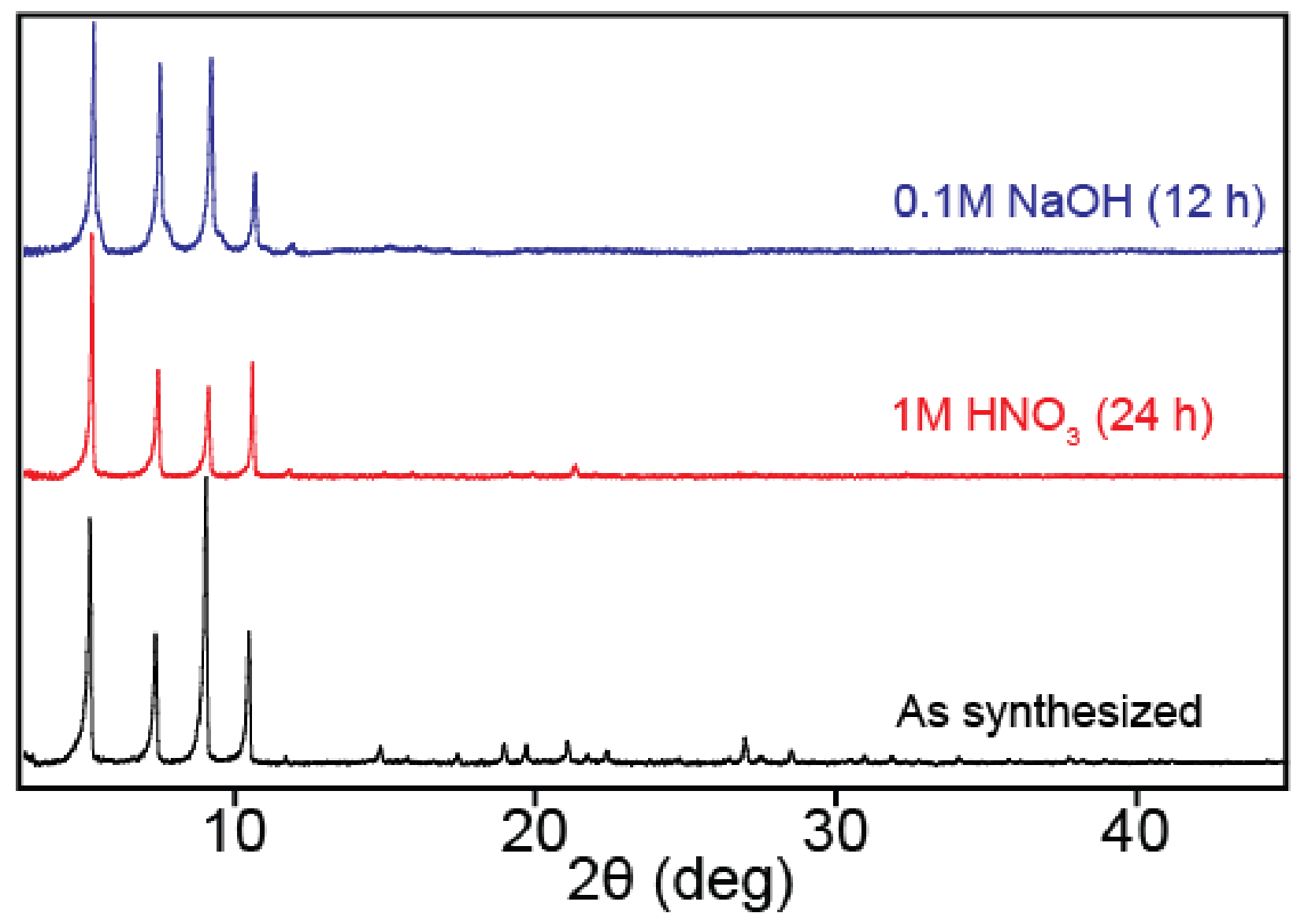

Figure S2. PXRD patterns of $\mathbf{1 - X}$ after activation and treatment with aqueous acid and base. Data was collected with $\mathrm{Cu} \mathrm{K} \alpha$ radiation. 


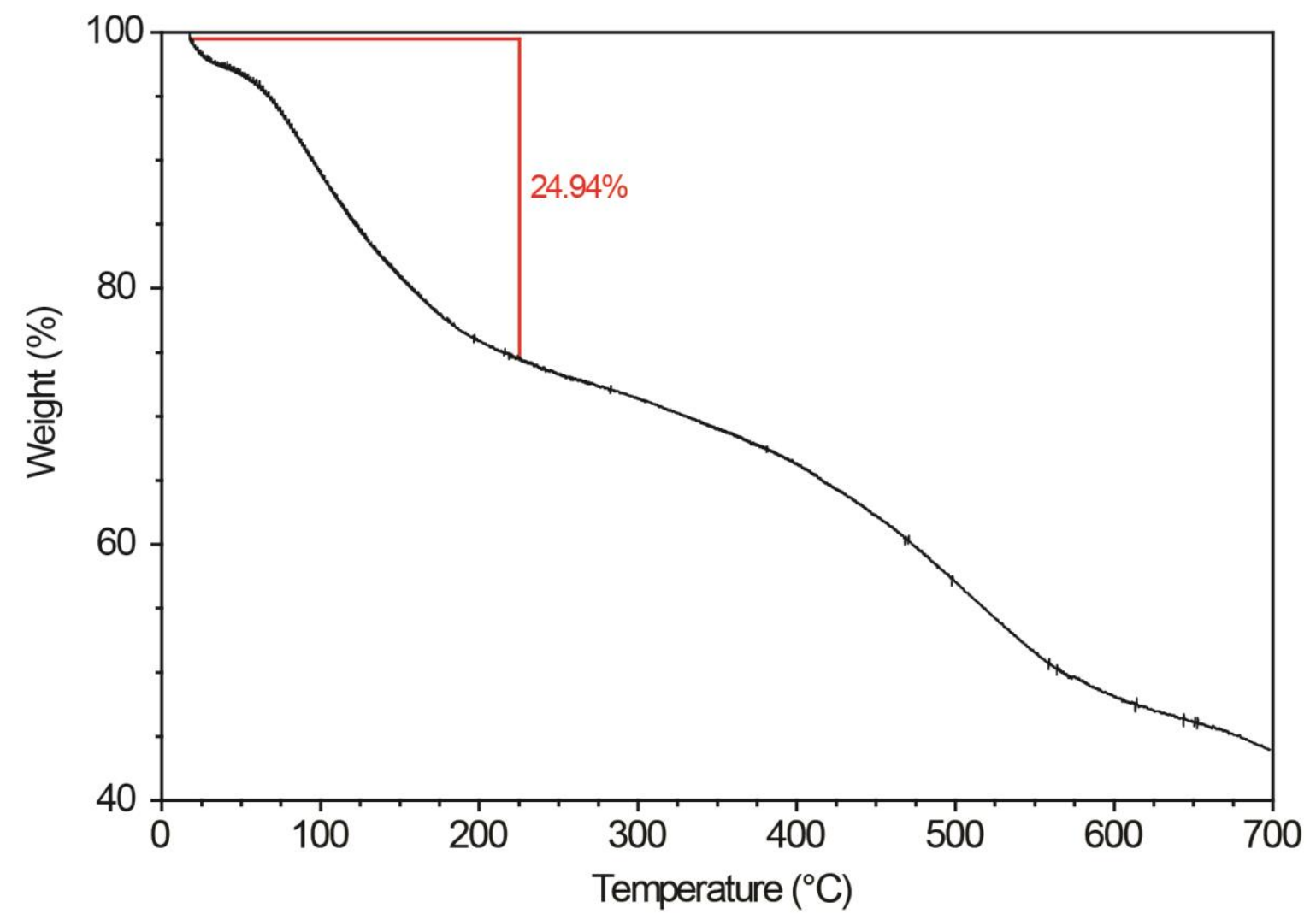

Figure S3. TGA data for $\mathbf{1 - X}$ measured using a ramp rate of $5{ }^{\circ} \mathrm{C} / \mathrm{min}$. 


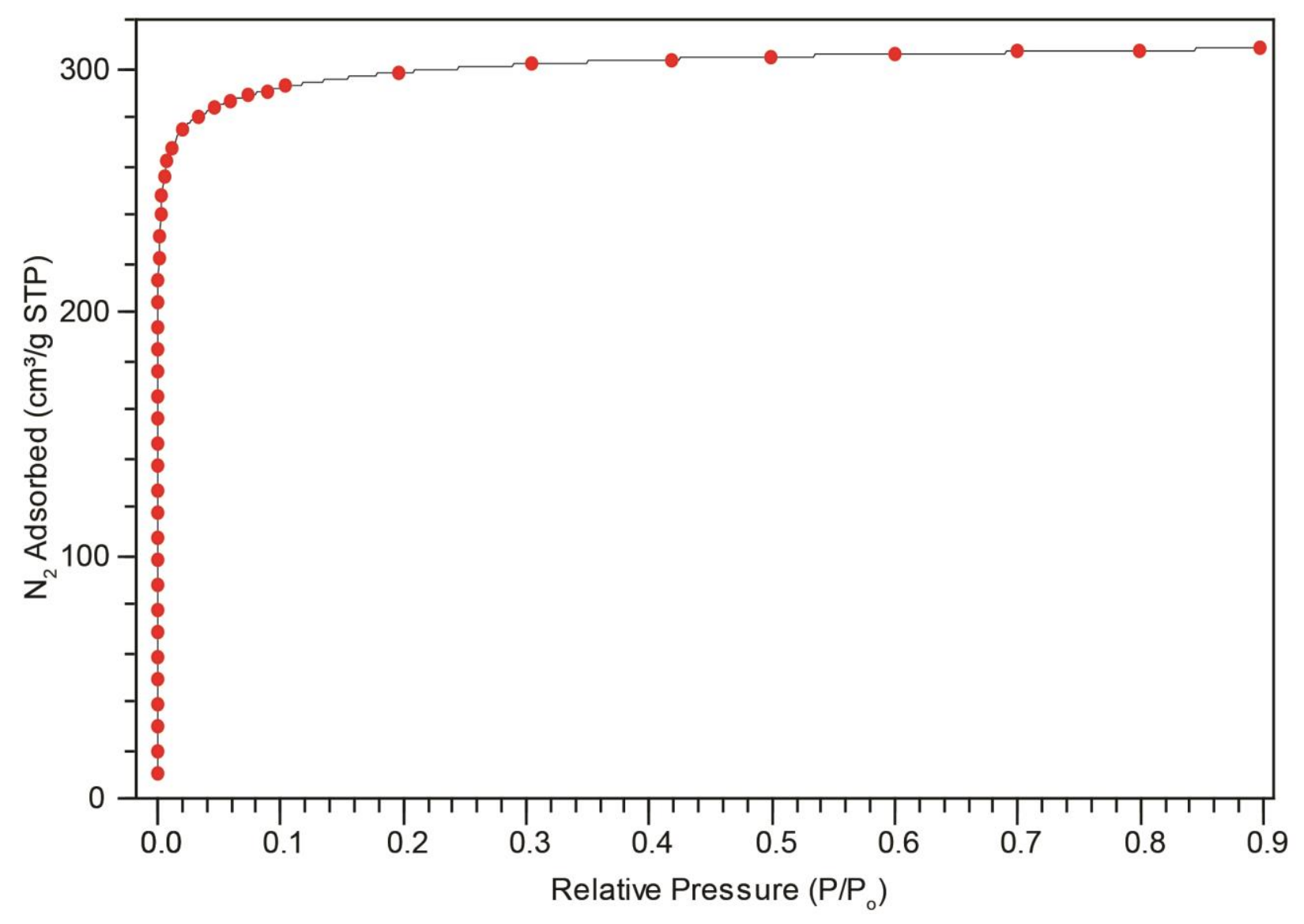

Figure S4. $\mathrm{N}_{2}$ adsorption isotherm $(77 \mathrm{~K})$ for $\mathbf{1 - X}$ (activated at $150{ }^{\circ} \mathrm{C}, 10^{-4}$ torr for $12 \mathrm{~h}$ ) 


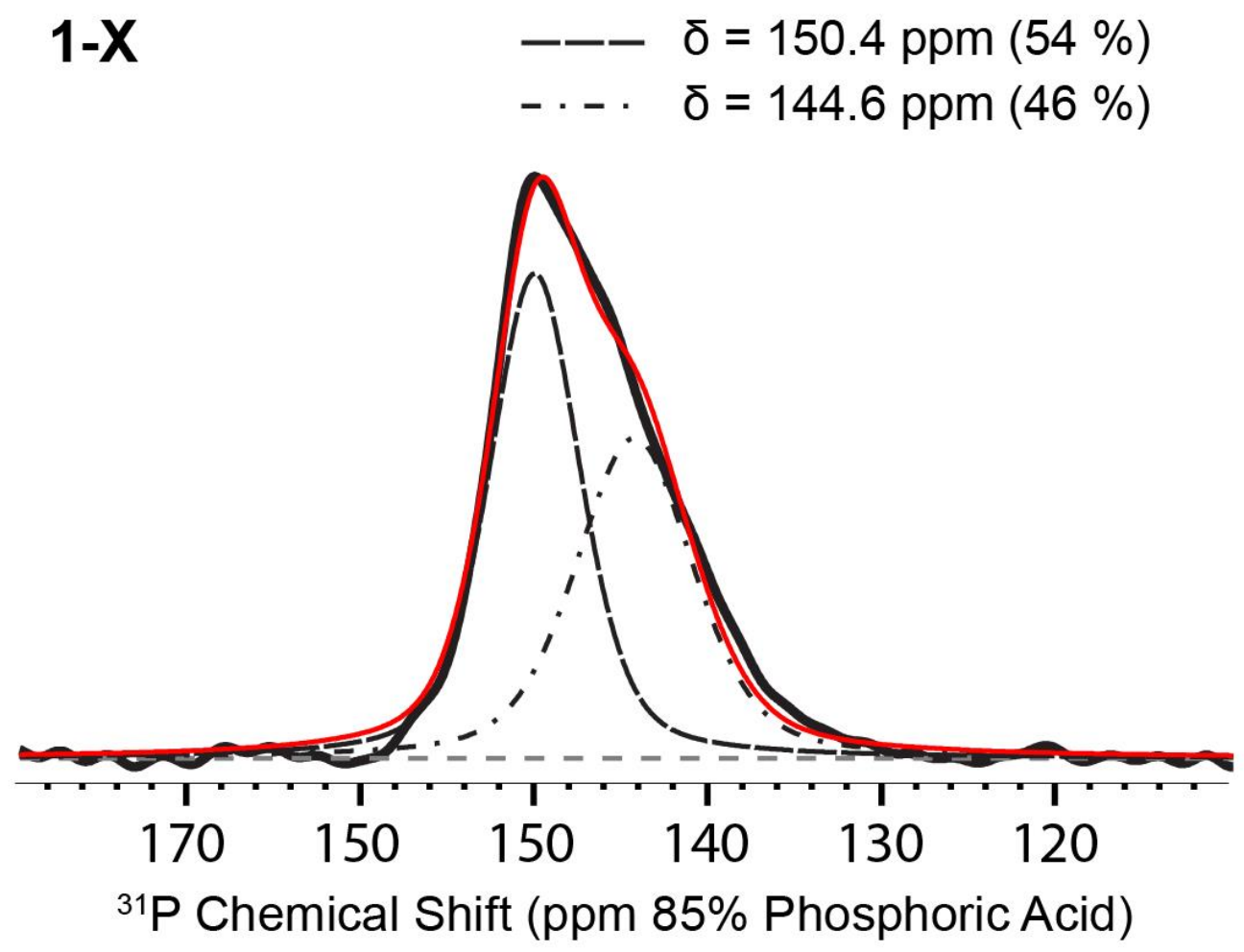

Figure S5. MAS ${ }^{31} \mathrm{P}$ NMR spectrum of $\mathbf{1 - X}$ showing peak deconvolution of major resonance. The black solid line is the experimental spectrum and red solid line is the fitted spectrum. 


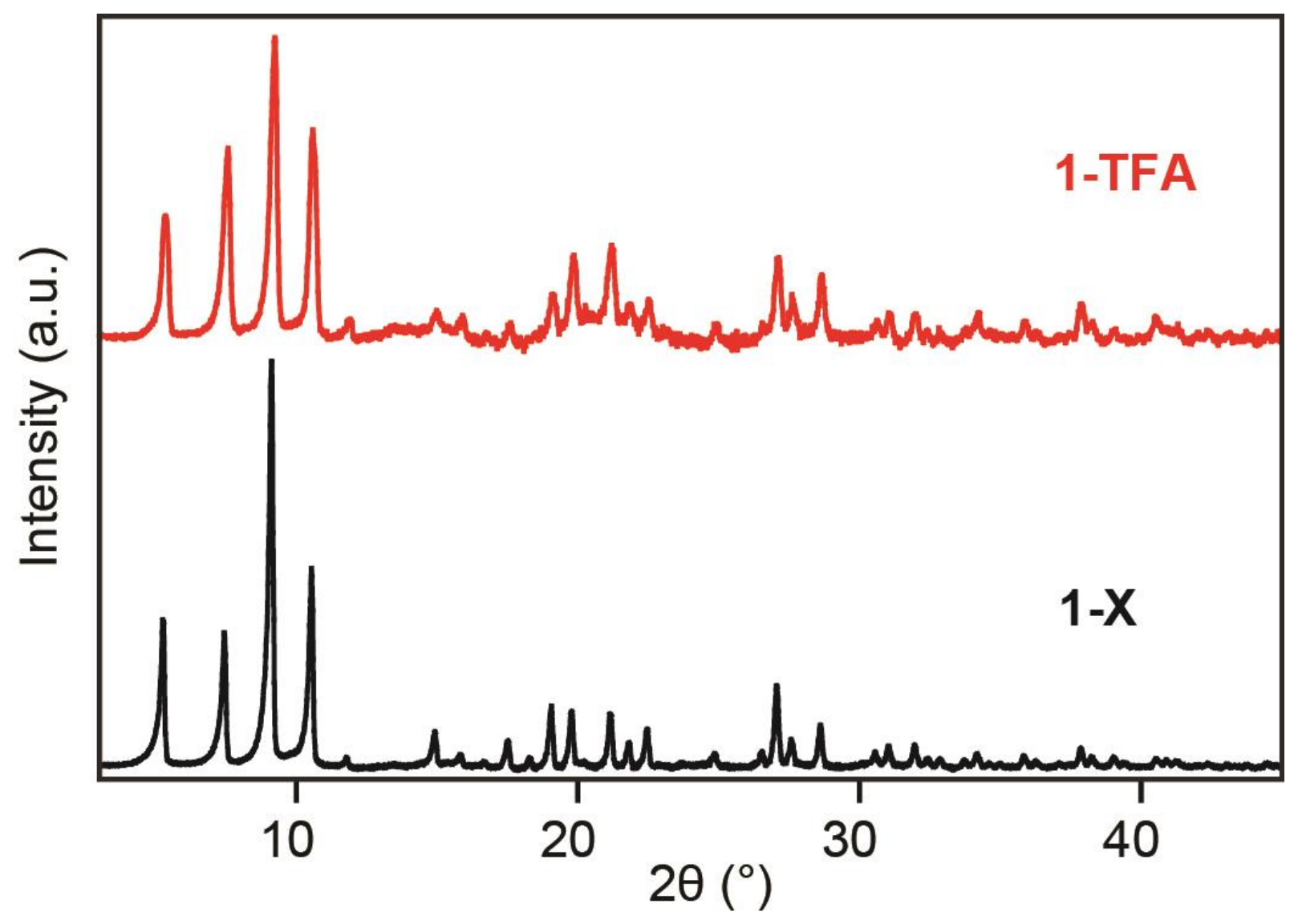

Figure S6. PXRD patterns of 1-X and 1-TFA. Data was collected with $\mathrm{Cu} \mathrm{K} \alpha$ radiation. 


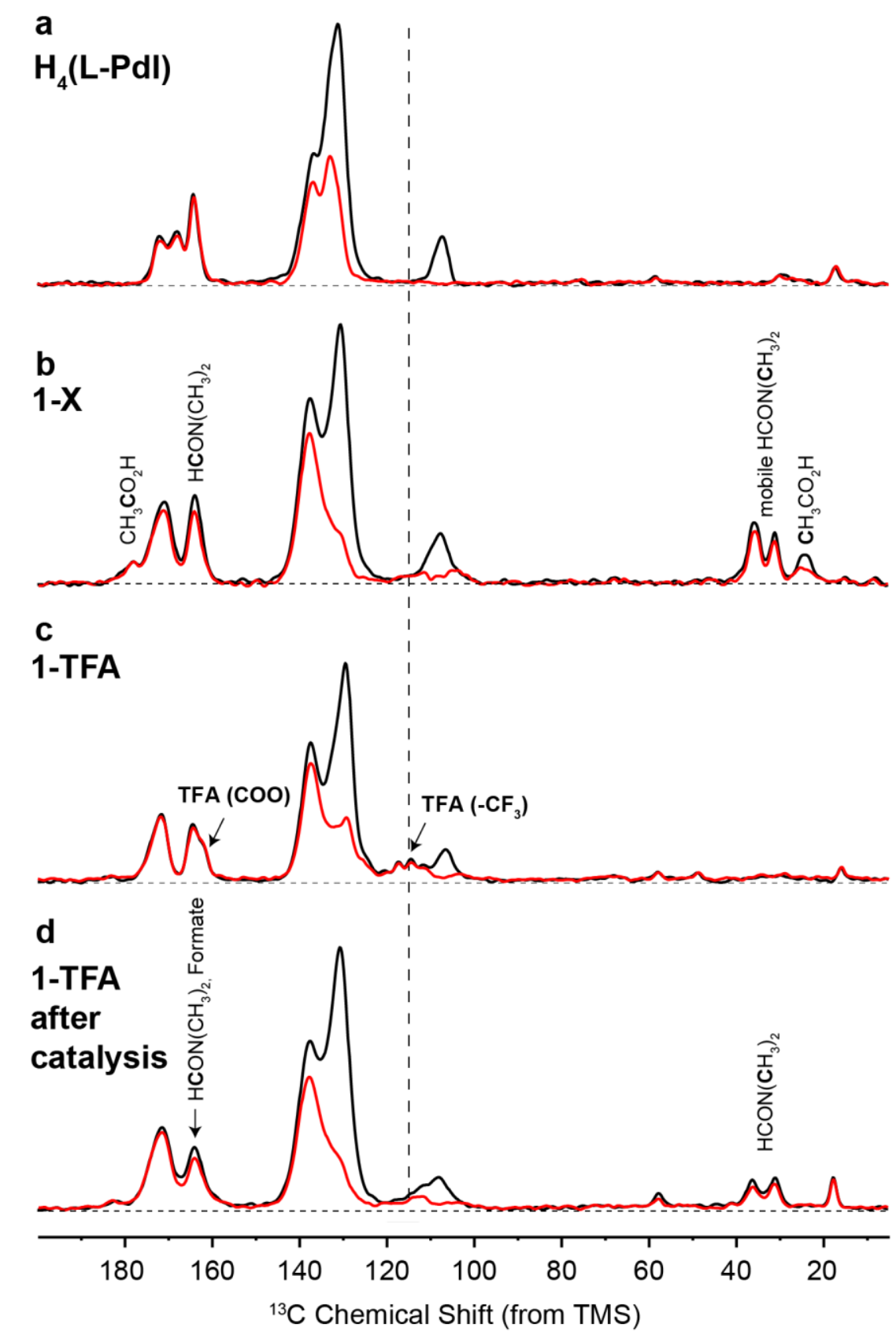

Figure S7. Overlay of the MAS ${ }^{13} \mathrm{C}$ NMR spectra of $\mathrm{H}_{4}(\mathrm{~L}-\mathrm{PdI})$ (a), 1-X (b), 1-TFA (c), and 1TFA after catalysis (d). Black - composite-pulse multi-CP, near-quantitative spectrum Red - spectrum with $68 \mu$ s of gated decoupling showing signals of ${ }^{13} \mathrm{C}$ nuclei without strongly coupled protons. 


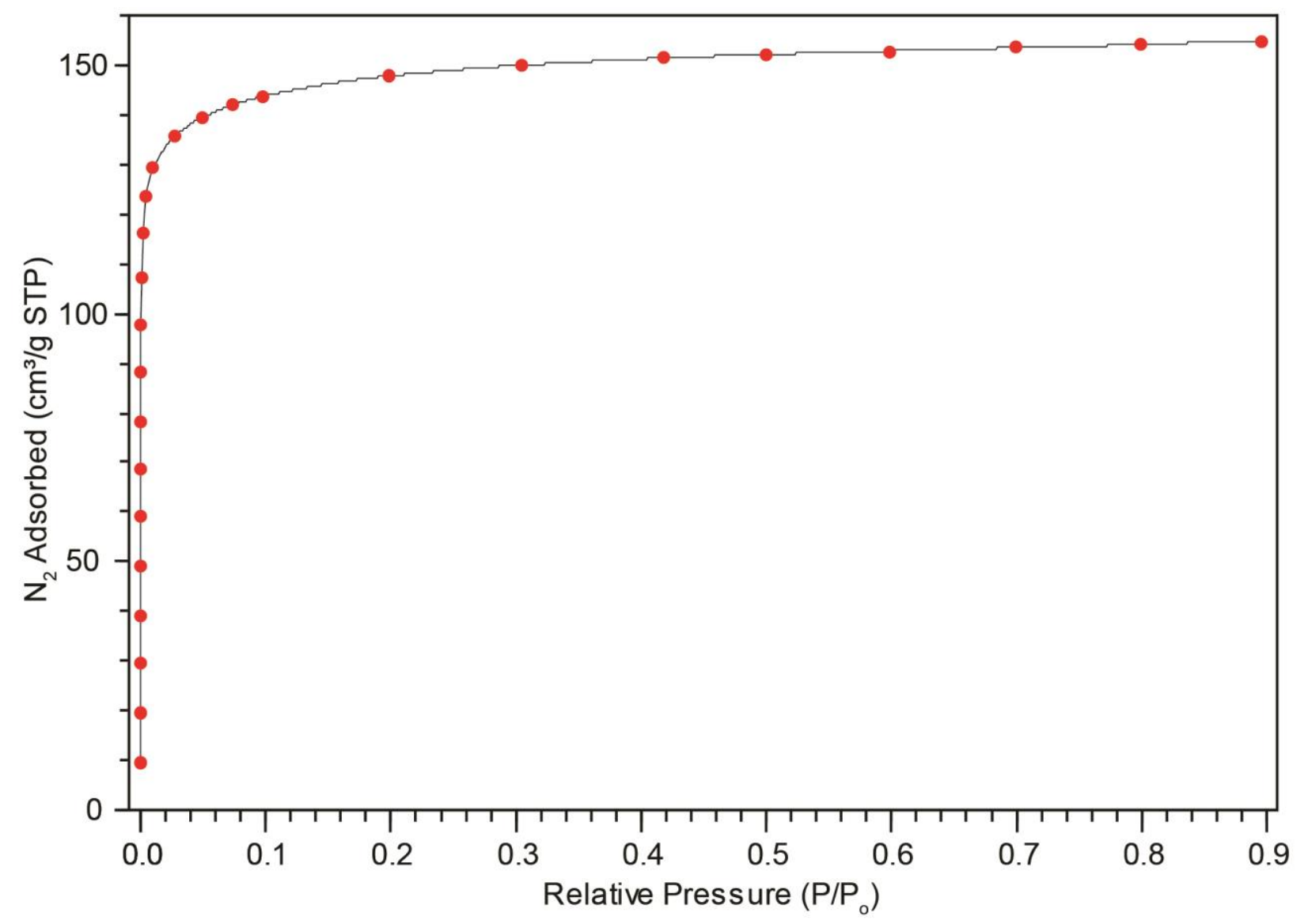

Figure S8. $\mathrm{N}_{2}$ adsorption isotherm of 1-TFA. 


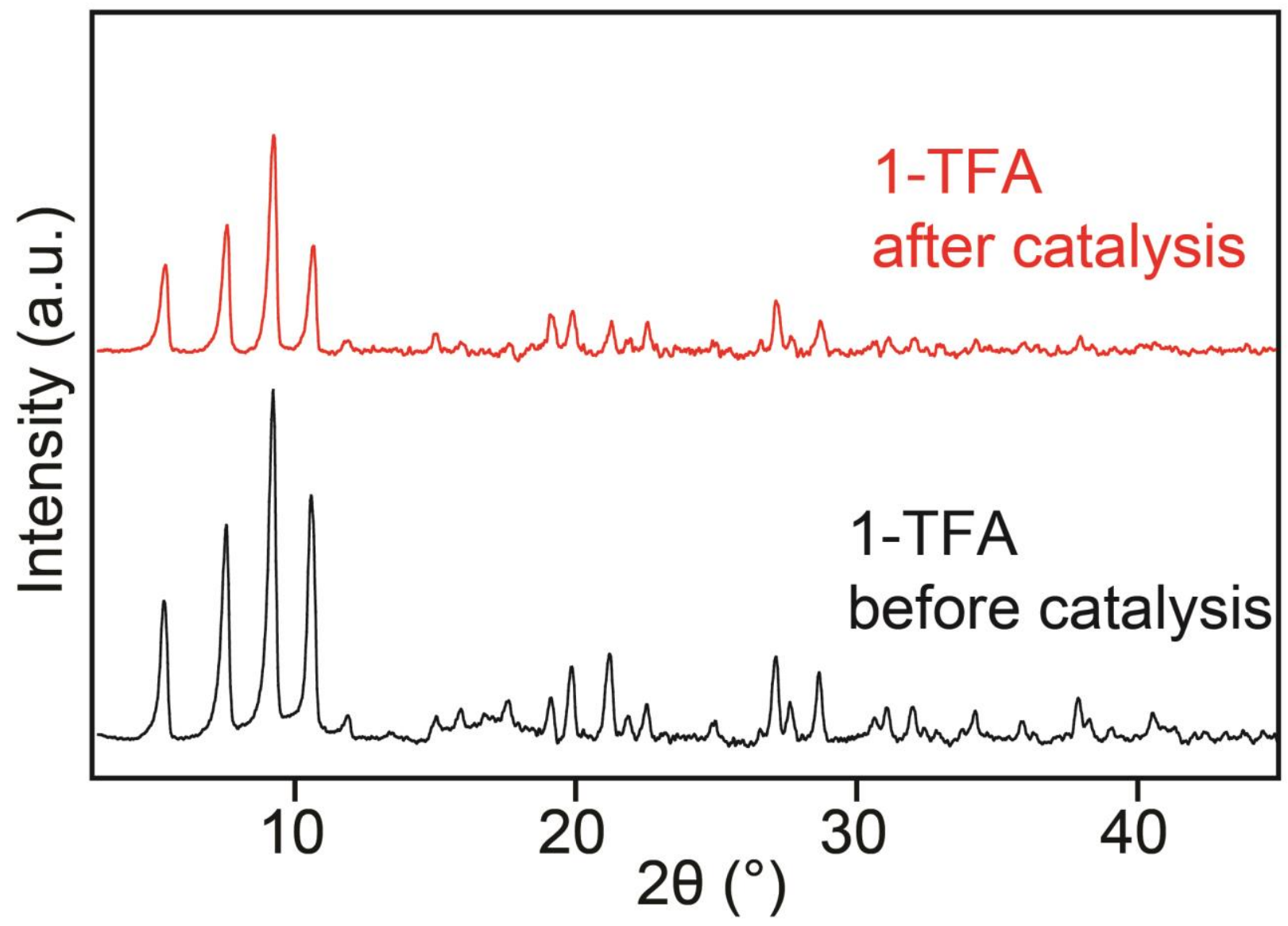

Figure S9. PXRD patterns of 1-TFA before and after catalysis. Data was collected with $\mathrm{Cu} \mathrm{K} \alpha$ radiation. 


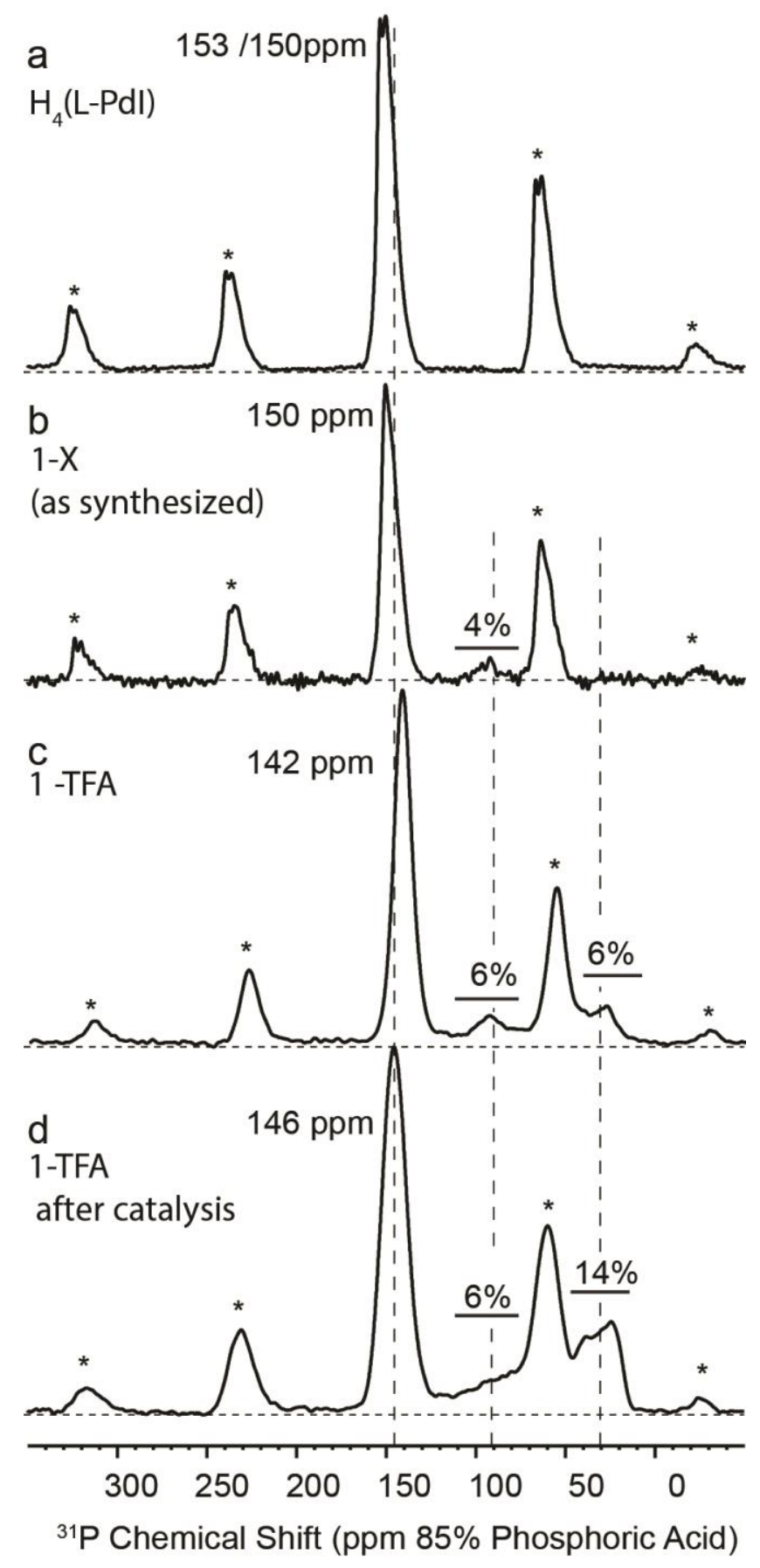

Figure S10. Overlay of the MAS ${ }^{31} \mathrm{P}$ NMR spectra of $\mathrm{H}_{4}(\mathrm{~L}-\mathrm{PdI})$ (a), 1-X (b), 1-TFA (c), and 1TFA after catalysis (d). The main phosphinite resonance shifts from ca. $150 \mathrm{ppm}$ to $142 \mathrm{ppm}$ after reaction with $\mathrm{PhI}(\mathrm{TFA})_{2}$. After catalysis the phosphinite resonance appears at $146 \mathrm{ppm}$. Spinning side bands at $14 \mathrm{kHz}$ intervals from the center resonance result from chemical shift anisotropy. Impurities resonate near $94 \mathrm{ppm}$ and $30 \mathrm{ppm}$. The impurity near $94 \mathrm{ppm}$ (integral from 75 to $115 \mathrm{ppm}$ ) accounts for $6 \pm 2 \%$ of the intensity in (c-d). The impurity near $30 \mathrm{ppm}$ grows from $6 \pm 2 \%$ (integral from 7 to $40 \mathrm{ppm}$ ) in the spectrum before catalysis (c) to $14 \pm 2 \%$ (integral from 7 to $45 \mathrm{ppm}$ ) after catalysis (d). 

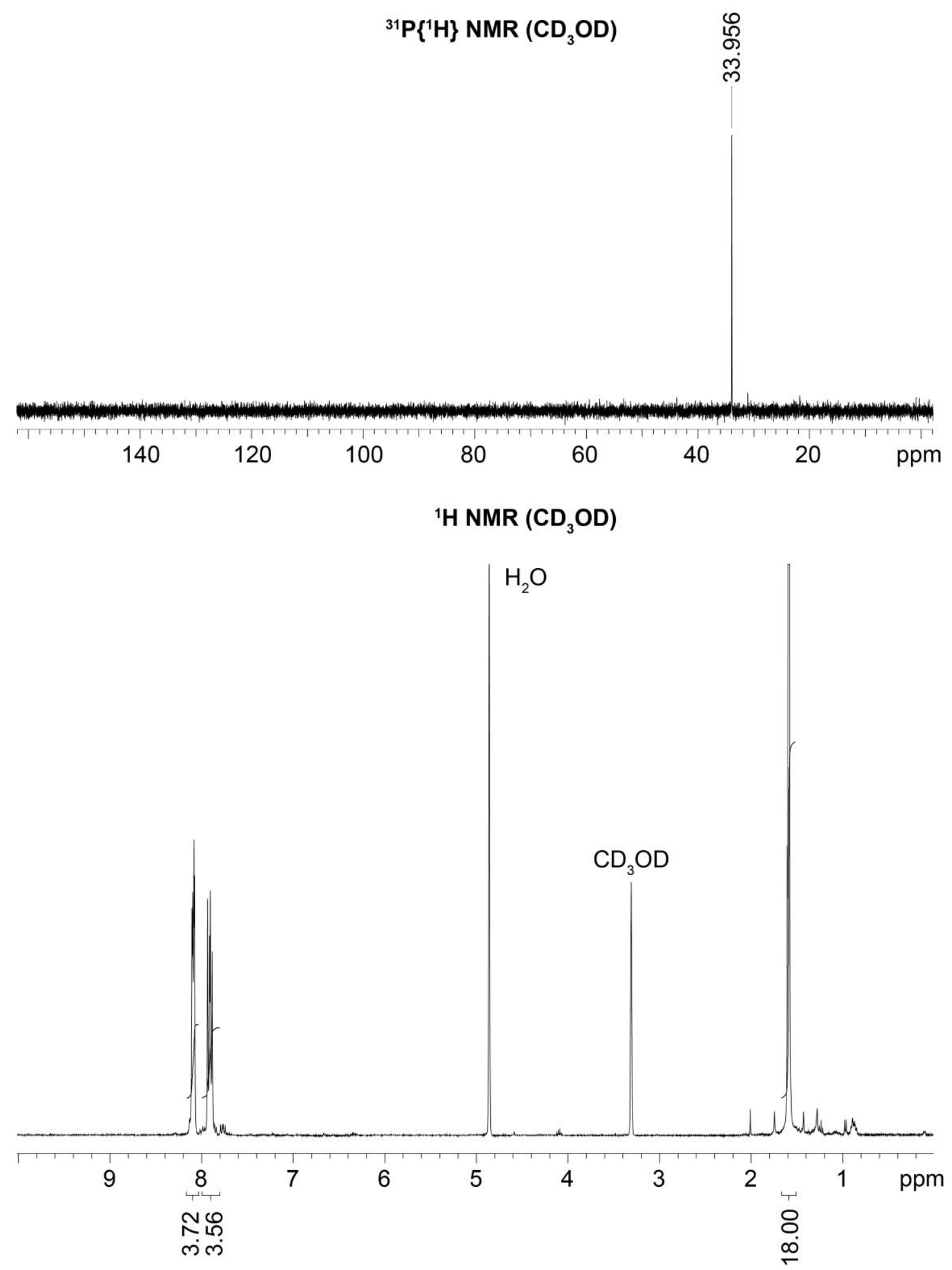

Figure S11. ${ }^{31} \mathrm{P}\left\{{ }^{1} \mathrm{H}\right\}$ and ${ }^{1} \mathrm{H}$ NMR spectra of $\left({ }^{\mathrm{t}} \mathrm{BuO}_{2} \mathrm{CPh}\right)_{2} \mathrm{P}(\mathrm{O}) \mathrm{OCD}_{3}$ isolated from reaction of ${ }^{\mathbf{t}} \mathbf{B u}_{4}\left(\right.$ L-PdTFA) with 4 equiv. of $\mathrm{HCO}_{2} \mathrm{Na}$ in $\mathrm{CD}_{3} \mathrm{OD}$. 


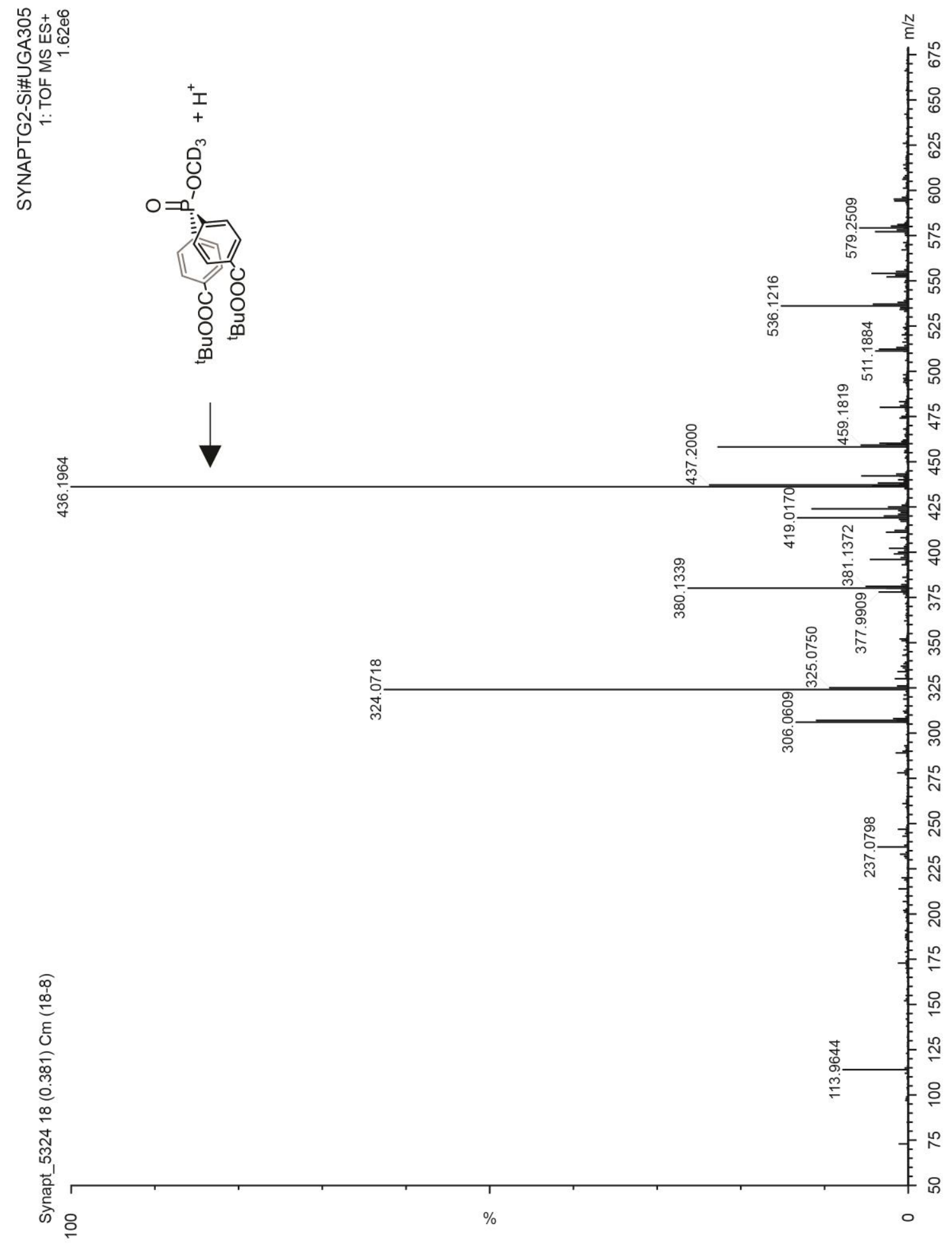

Figure S12. ESI mass spectrum of $\left({ }^{\mathrm{t}} \mathrm{BuO}{ }_{2} \mathrm{CPh}\right)_{2} \mathrm{P}(\mathrm{O}) \mathrm{OCD}_{3}$ isolated from reaction of ${ }^{\mathrm{t}} \mathbf{B u}_{4}(\mathbf{L}$ PdTFA) with 4 equiv. of $\mathrm{HCO}_{2} \mathrm{Na}$ in $\mathrm{CD}_{3} \mathrm{OD}$. 
${ }^{31} \mathrm{P}\left\{{ }^{1} \mathrm{H}\right\} \mathrm{NMR}\left(\mathrm{CDCl}_{3}\right)$

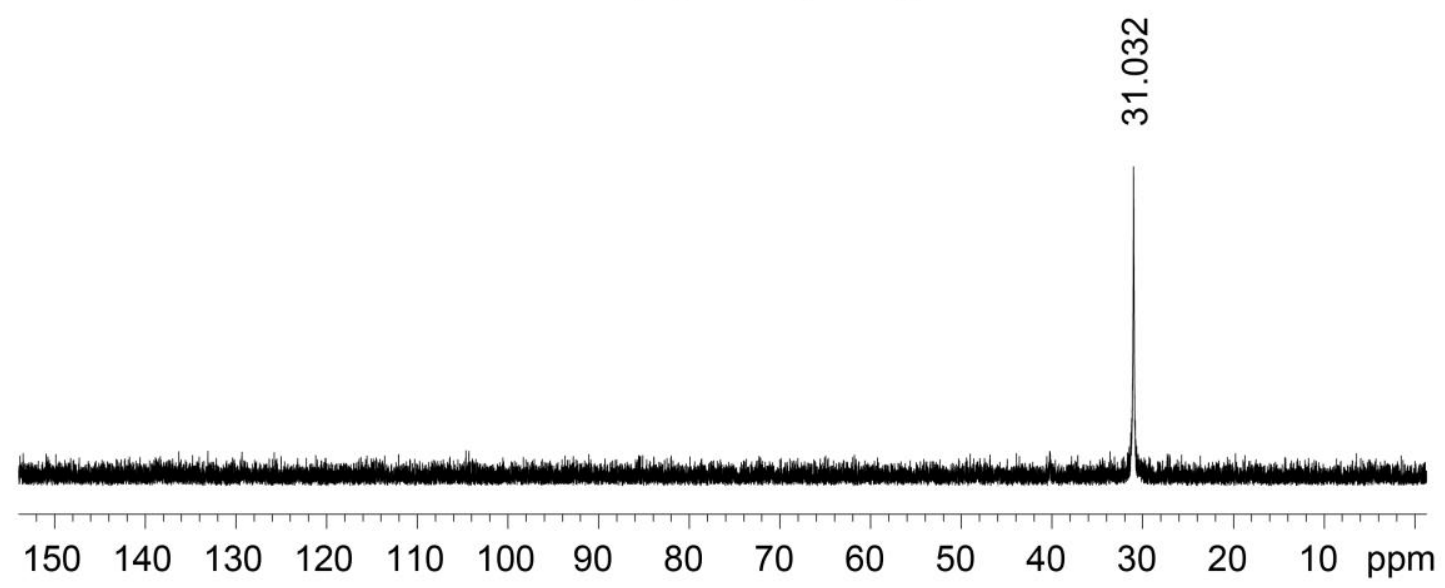

${ }^{1} \mathrm{H}$ NMR $\left(\mathrm{CDCl}_{3}\right)$

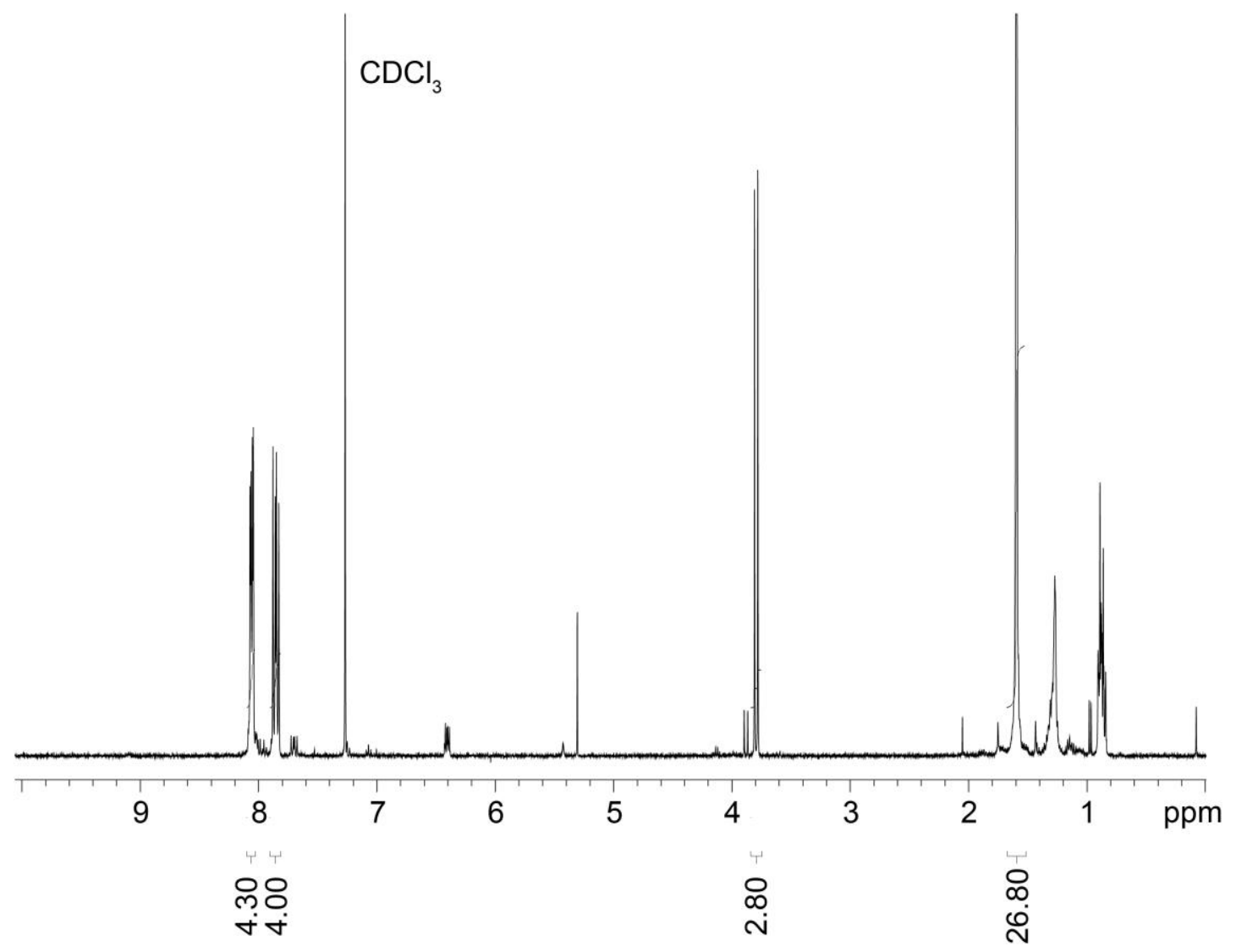

Figure S13. ${ }^{31} \mathrm{P}\left\{{ }^{1} \mathrm{H}\right\}$ and ${ }^{1} \mathrm{H}$ NMR spectra of $\left({ }^{\mathrm{t}} \mathrm{BuO}_{2} \mathrm{CPh}\right)_{2} \mathrm{P}(\mathrm{O}) \mathrm{OCH}_{3}$ isolated from reaction of ${ }^{\mathbf{t}} \mathbf{B u}_{4}\left(\mathbf{L}\right.$-PdTFA) with 4 equiv. of $\mathrm{HCO}_{2} \mathrm{Na}$ in $\mathrm{CH}_{3} \mathrm{OH}$. 


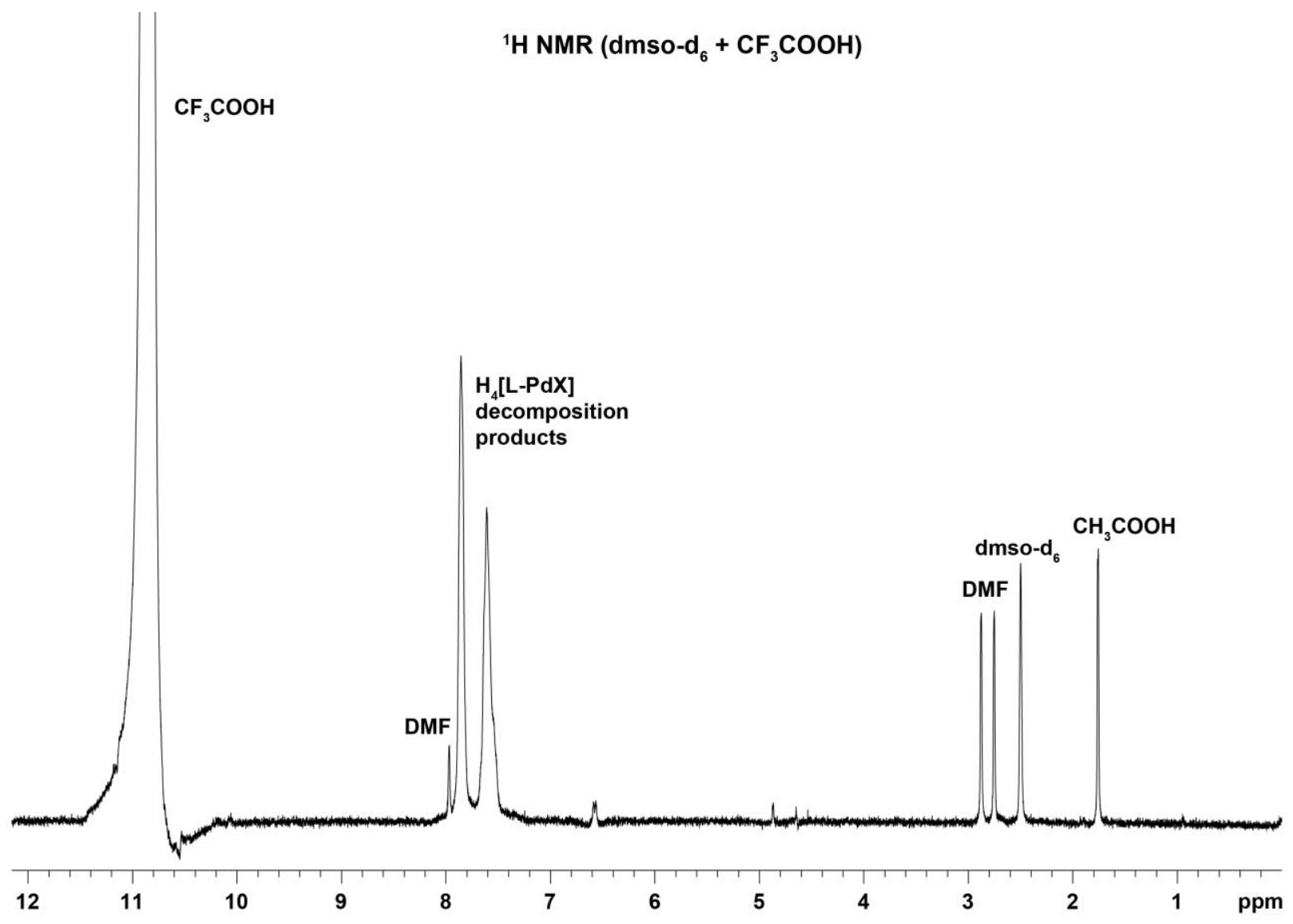

Figure S14. ${ }^{1} \mathrm{H}$ NMR spectrum of an acid-digested $\left(0.1 \mathrm{~mL} \mathrm{CF}_{3} \mathrm{COOH} / 0.5 \mathrm{~mL}\right.$ dmso-d $\left.\mathrm{d}_{6}\right)$ sample of activated 1-X. The amount of DMF and $\mathrm{CH}_{3} \mathrm{COOH}$ present in $\mathbf{1 - X}$ could not accurately be determined due to incomplete digestion of the MOF and decomposition of $\mathrm{H}_{4}(\mathrm{~L}-\mathrm{PdX})$. 


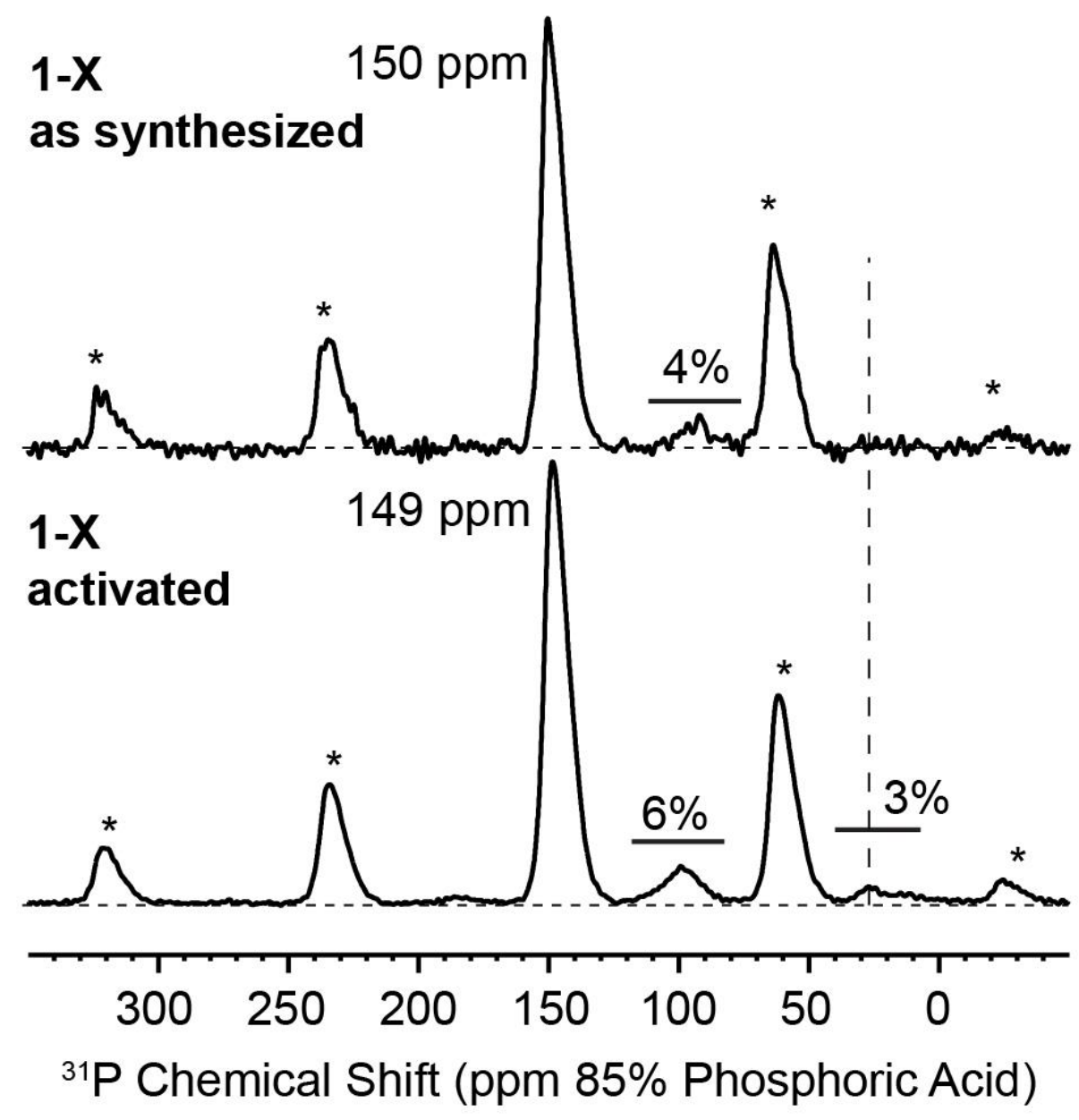

Figure S15. MAS ${ }^{31} \mathrm{P}$ NMR spectra of $\mathbf{1 - X}$ before and after activation. 


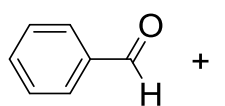

A
$\mathrm{HCO}_{2} \mathrm{Na}(1$ eq. $) \quad \mathbf{1 - X}(5 \mathrm{~mol} \% \mathrm{Pd})$ $\mathrm{HCO}_{2} \mathrm{H}$ (3 eq.) $\quad \mathrm{H}_{2} \mathrm{O} / \mathrm{MeOH}(1: 1)$

$60{ }^{\circ} \mathrm{C}, 12 \mathrm{~h}$

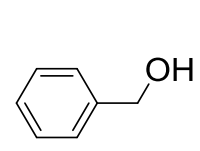

B
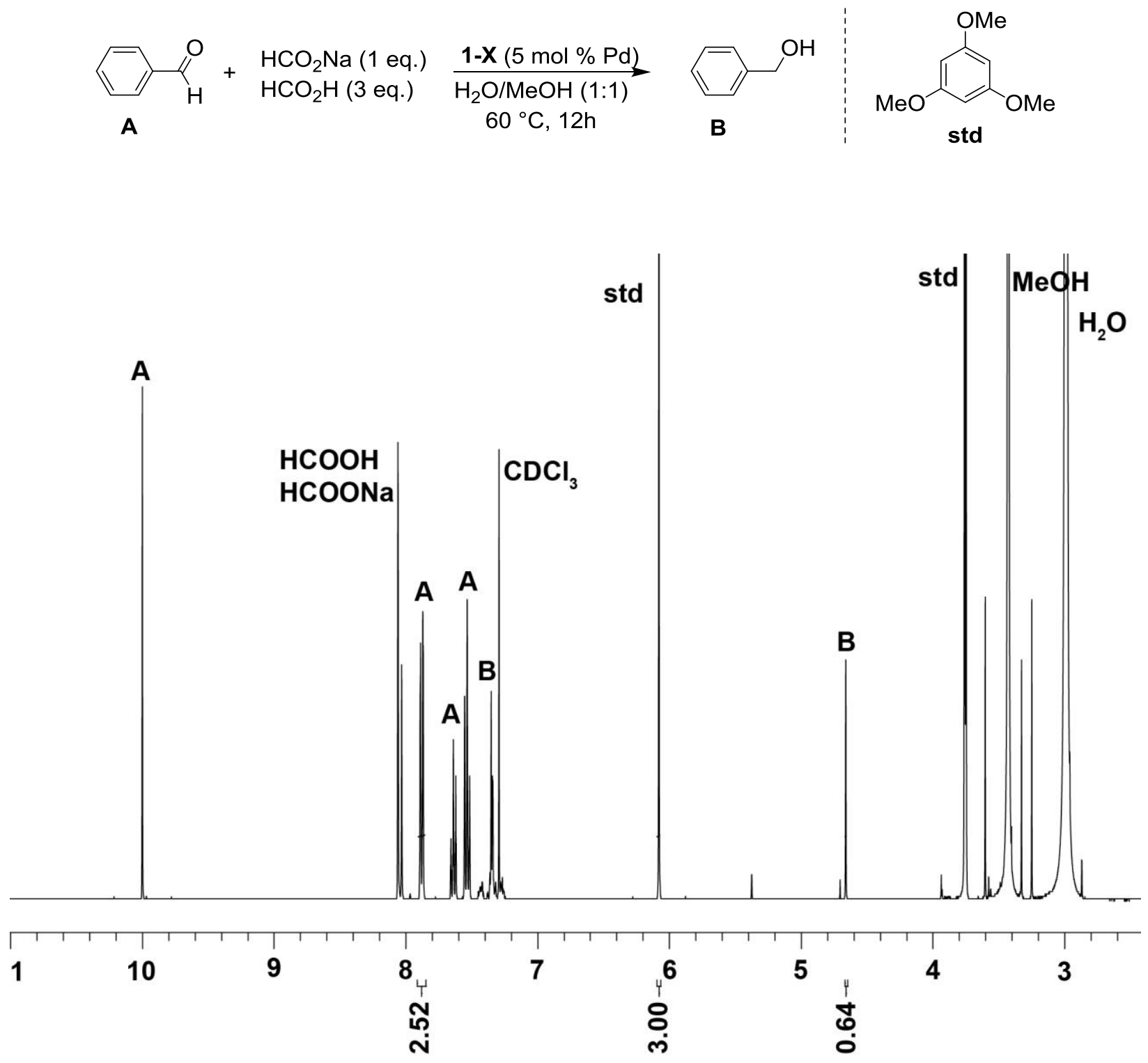

Figure S16. ${ }^{1} \mathrm{H}$ NMR spectrum of $\mathrm{CDCl}_{3}$ extracted products after catalytic transfer hydrogenation of benzaldehyde with $\mathbf{1 - X}(5 \mathrm{~mol} \%)$ as catalyst (Table 1 , entry 1$)$. 


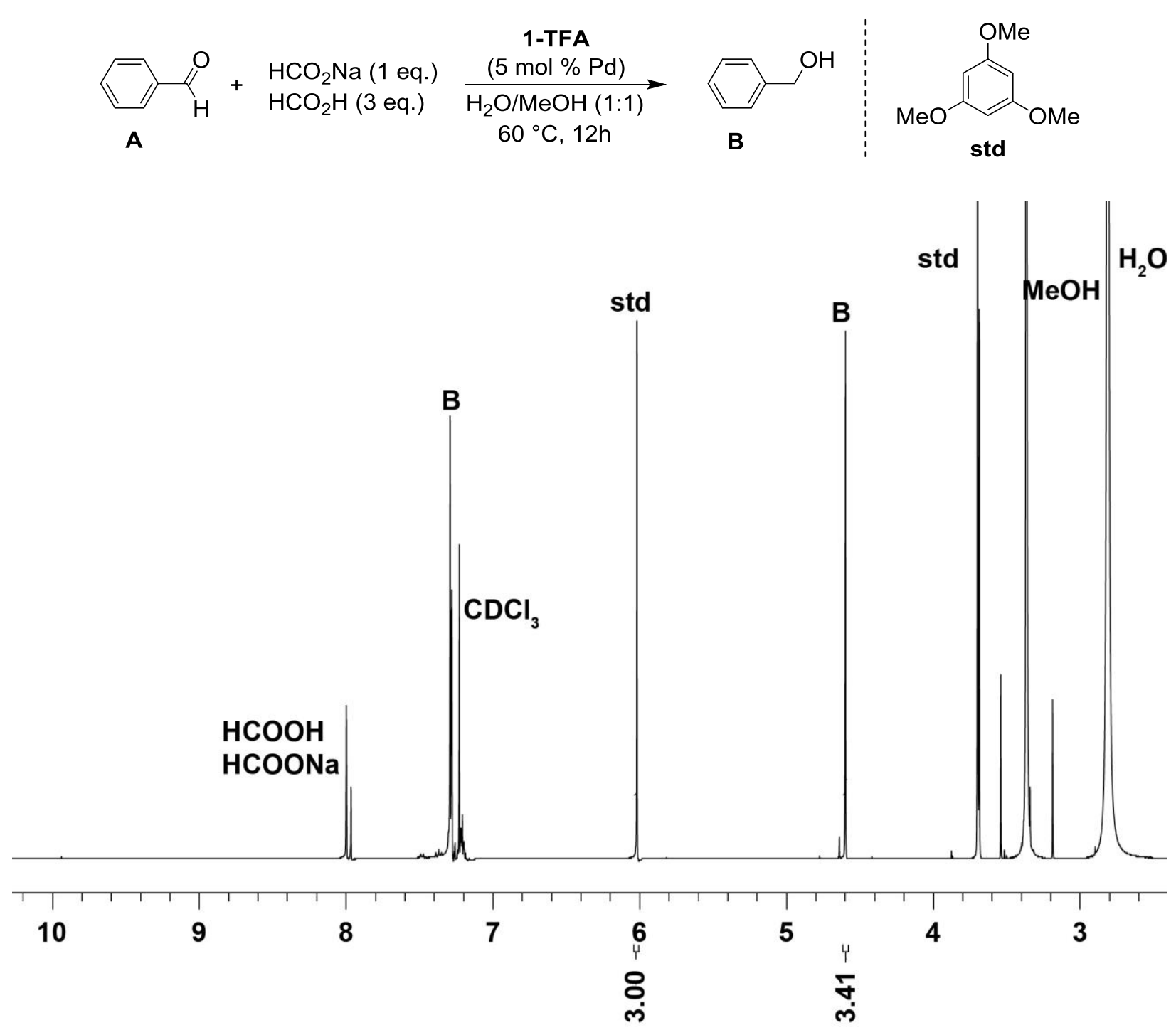

Figure S17. ${ }^{1} \mathrm{H}$ NMR spectrum of $\mathrm{CDCl}_{3}$ extracted products after catalytic transfer hydrogenation of benzaldehyde with 1-TFA (5 mol \%) as catalyst (Table 1, entry 2). 

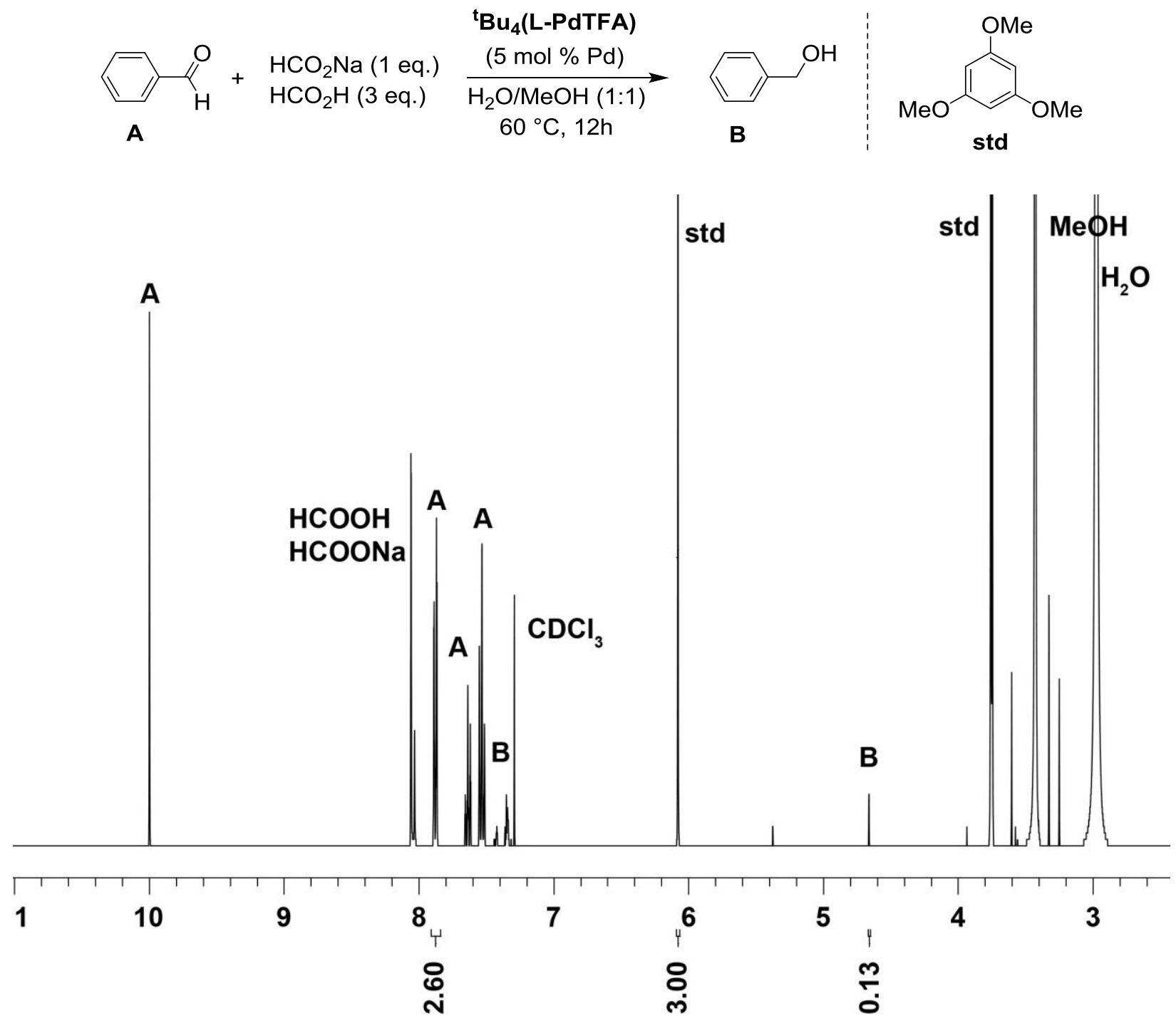

Figure S18. ${ }^{1} \mathrm{H}$ NMR spectrum of $\mathrm{CDCl}_{3}$ extracted products after catalytic transfer hydrogenation of benzaldehyde with ${ }^{\mathbf{t}} \mathbf{B u}_{\mathbf{4}}(\mathbf{L}$-PdTFA) $(5 \mathrm{~mol} \%)$ as catalyst (Table 1, entry 9). 

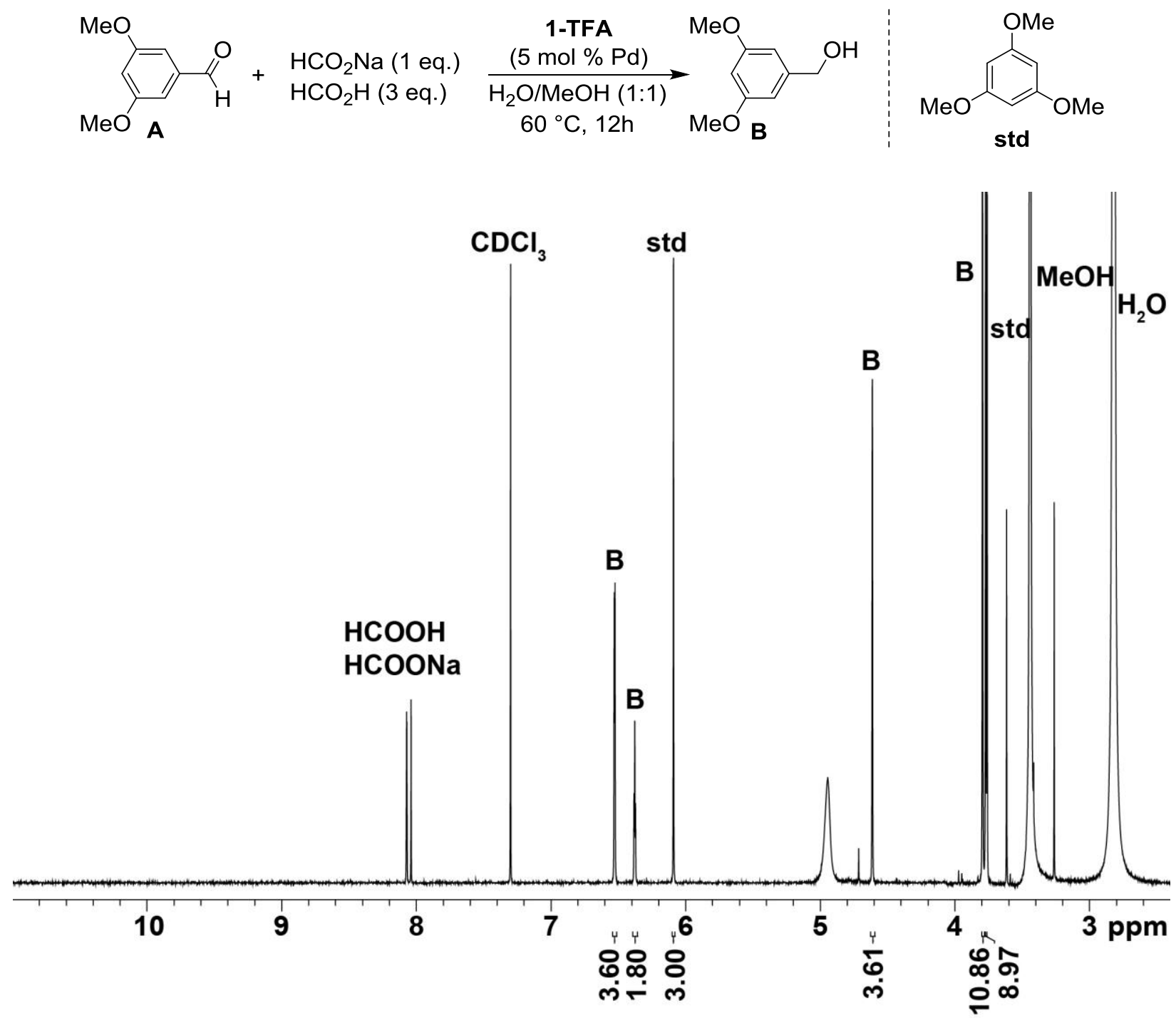

Figure S19. ${ }^{1} \mathrm{H}$ NMR spectrum of $\mathrm{CDCl}_{3}$ extracted products after catalytic transfer hydrogenation of 3,5-dimethoxybenzaldehyde with 1-TFA $(5 \mathrm{~mol} \%)$ as catalyst (Table 1 , entry 5). 

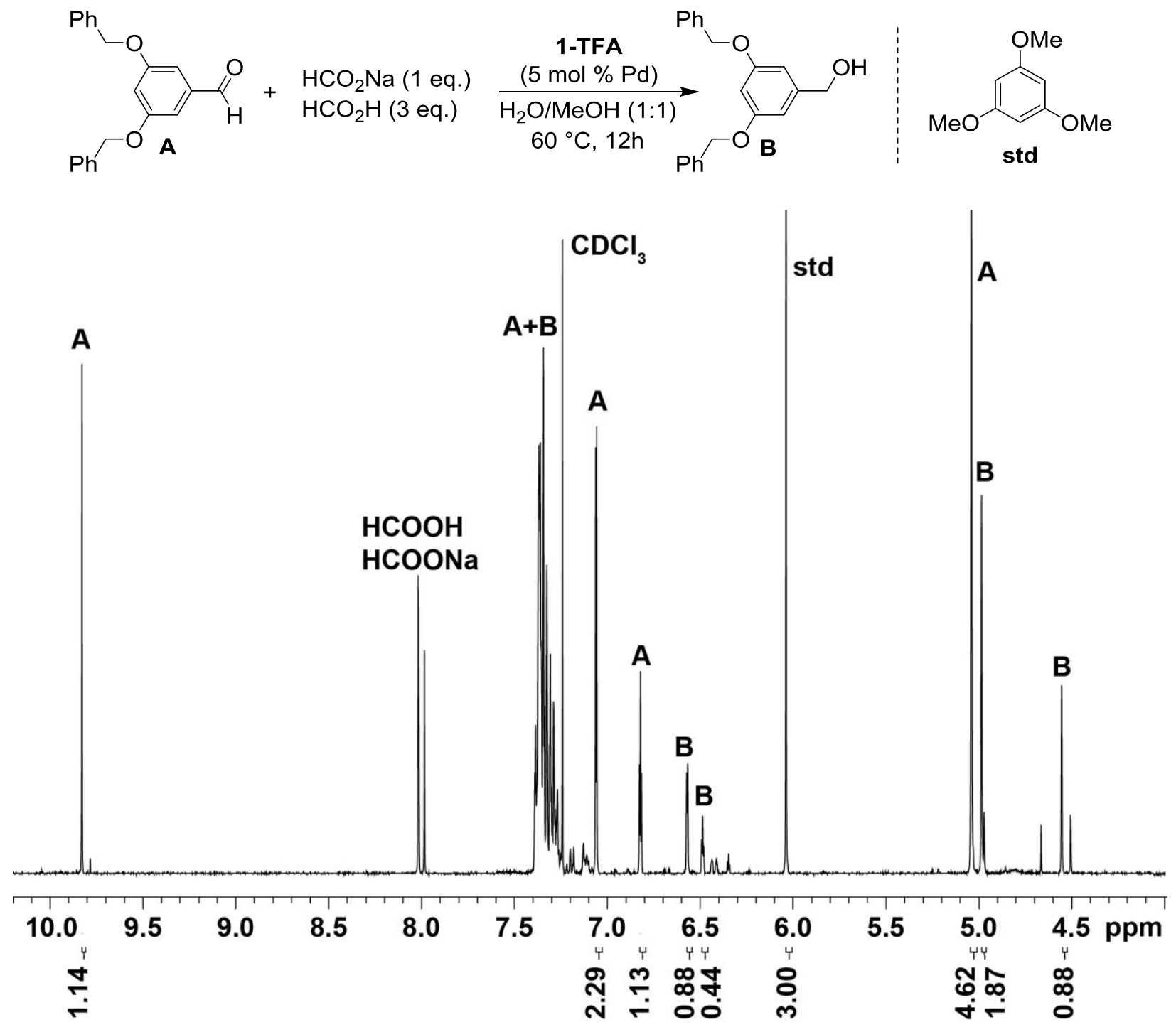

Figure S20. ${ }^{1} \mathrm{H}$ NMR spectrum of $\mathrm{CDCl}_{3}$ extracted products after catalytic transfer hydrogenation of 3,5-dibenzyloxybenzaldehyde with 1-TFA (5 mol \%) as catalyst (Table 1, entry 6). 


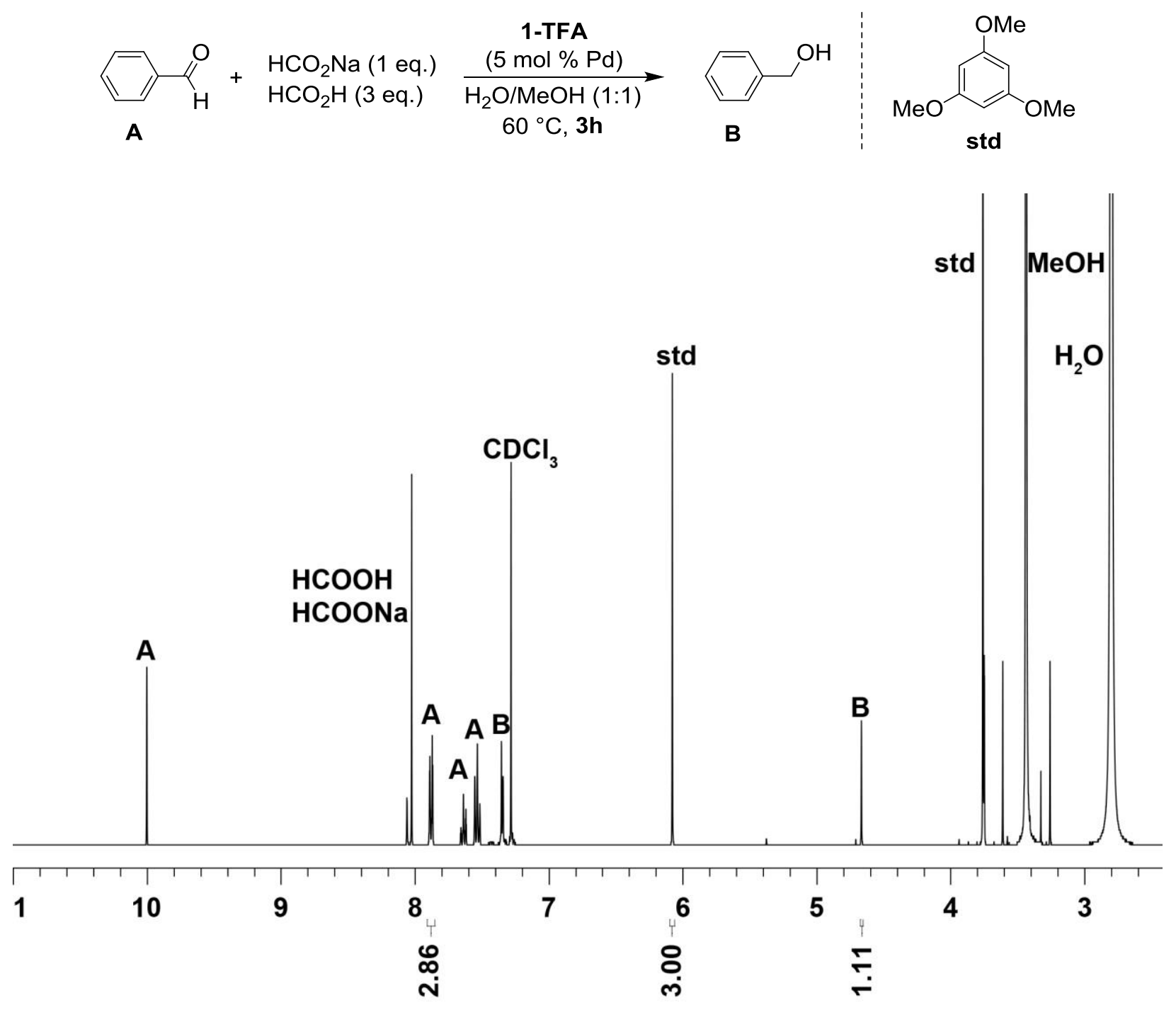

Figure S21. ${ }^{1} \mathrm{H}$ NMR of aliquot of reaction mixture (before hot filtration) extracted with $\mathrm{CDCl}_{3}$ after $3 \mathrm{~h}$. 


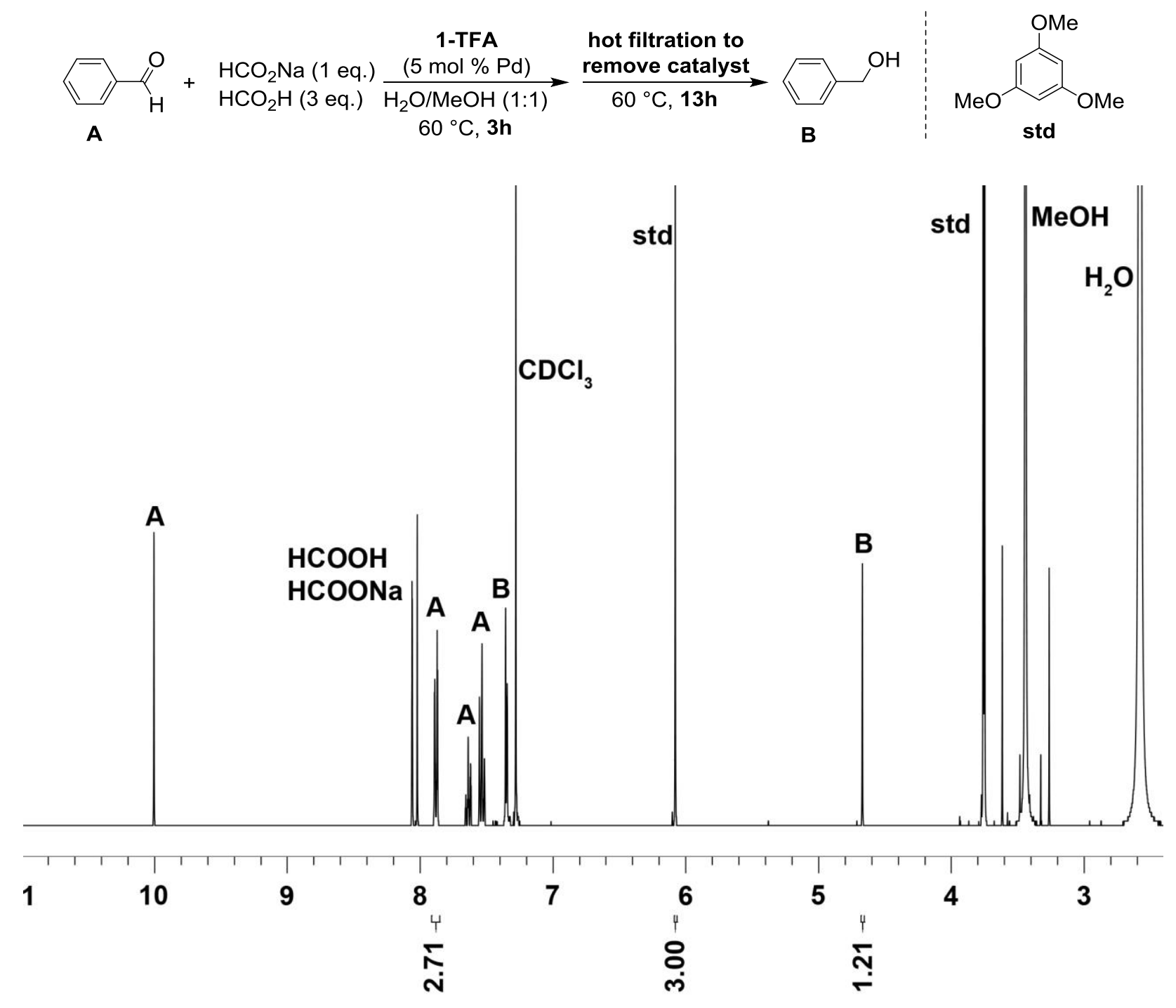

Figure S22. ${ }^{1} \mathrm{H}$ NMR of products extracted with $\mathrm{CDCl}_{3}$ after hot filtration at $3 \mathrm{~h}$ and continued heating of filtrate for $13 \mathrm{~h}$ at $60{ }^{\circ} \mathrm{C}$. 

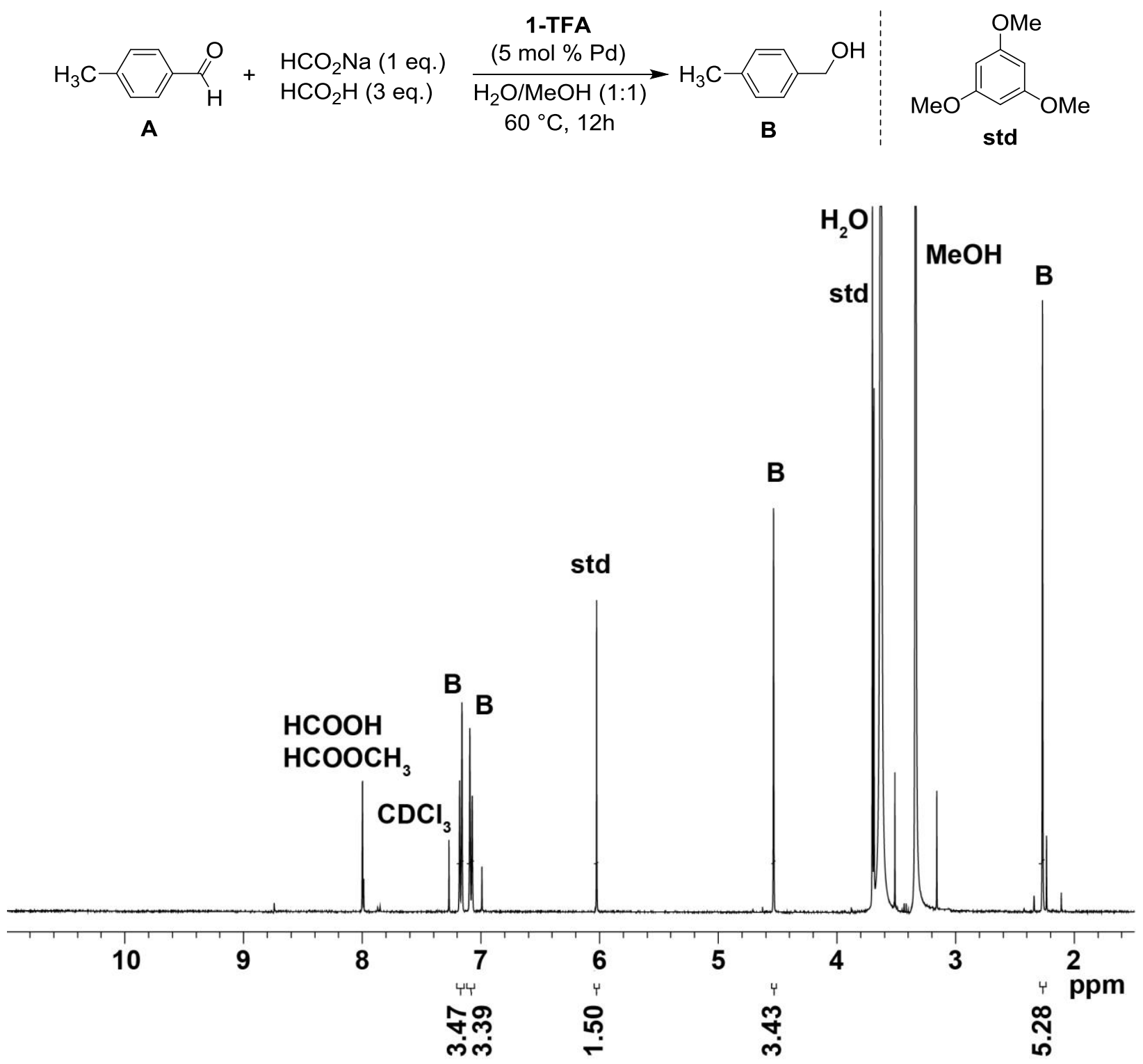

Figure S23. ${ }^{1} \mathrm{H}$ NMR spectrum of $\mathrm{CDCl}_{3}$ extracted products after catalytic transfer hydrogenation of $p$-tolualdehyde (Table S1, entry 1) with 1-TFA (5 mol \%) as catalyst. 0.5 mmol of 1,3,5-trimethoxybenzene added as an internal standard. 

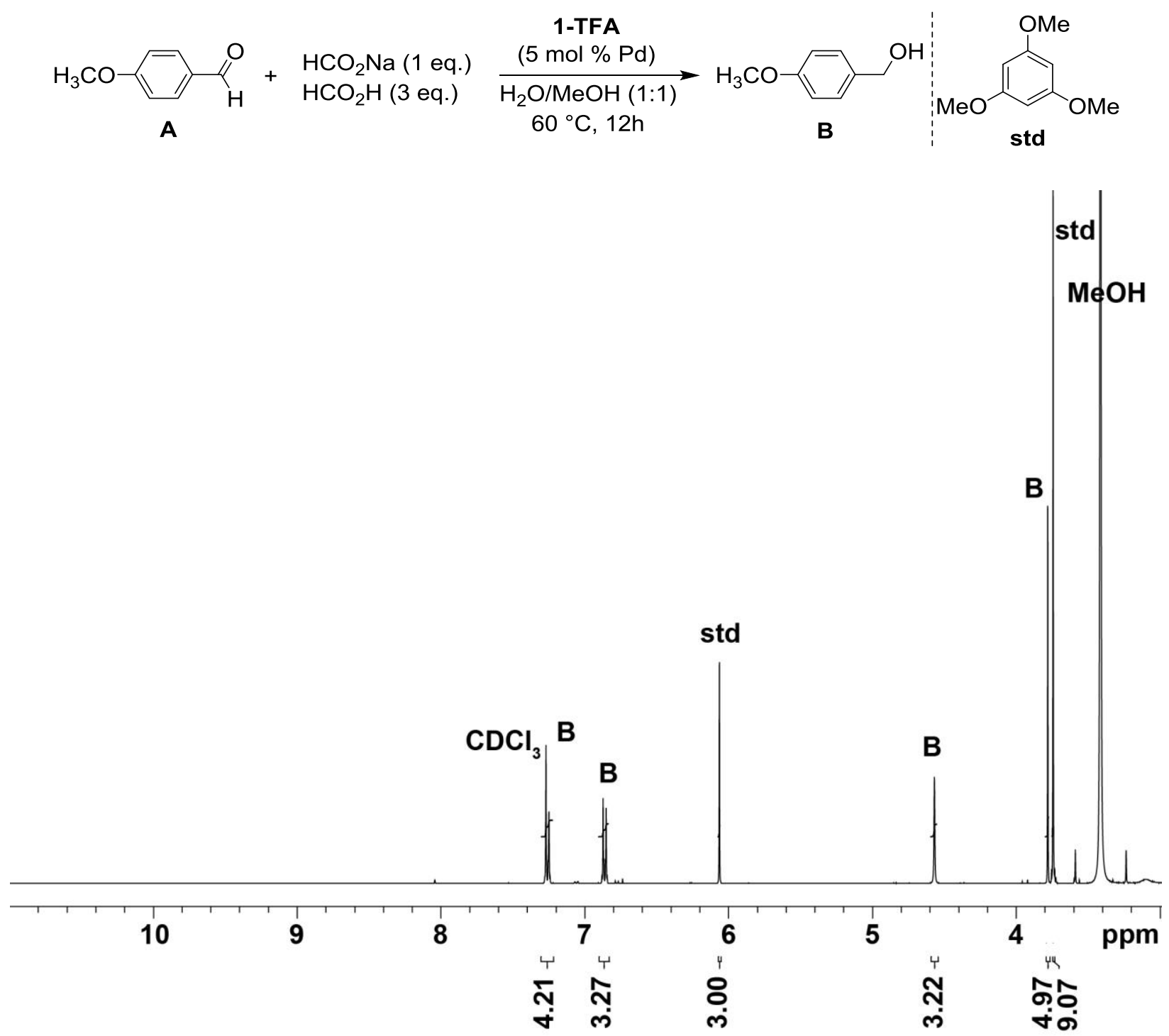

Figure S24. ${ }^{1} \mathrm{H}$ NMR spectrum of $\mathrm{CDCl}_{3}$ extracted products after catalytic transfer hydrogenation of 4-methoxybenzaldehyde (Table S1, entry 2) with 1-TFA (5 mol \%) as catalyst. 

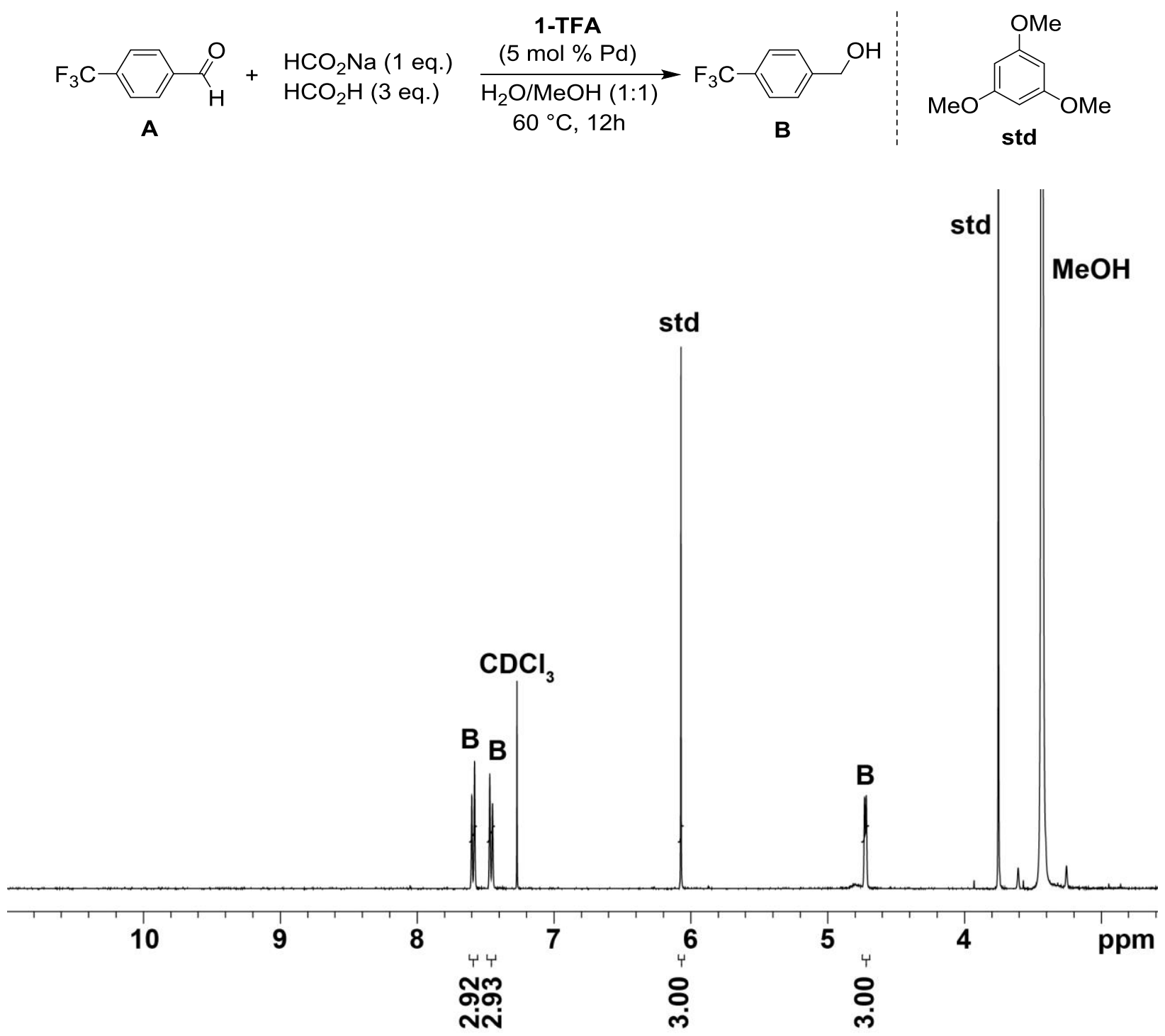

Figure S25. ${ }^{1} \mathrm{H}$ NMR spectrum of $\mathrm{CDCl}_{3}$ extracted products after catalytic transfer hydrogenation of 4-trifluoromethylbenzaldehyde (Table S1, entry 3) with 1-TFA (5 mol \%) as catalyst. 

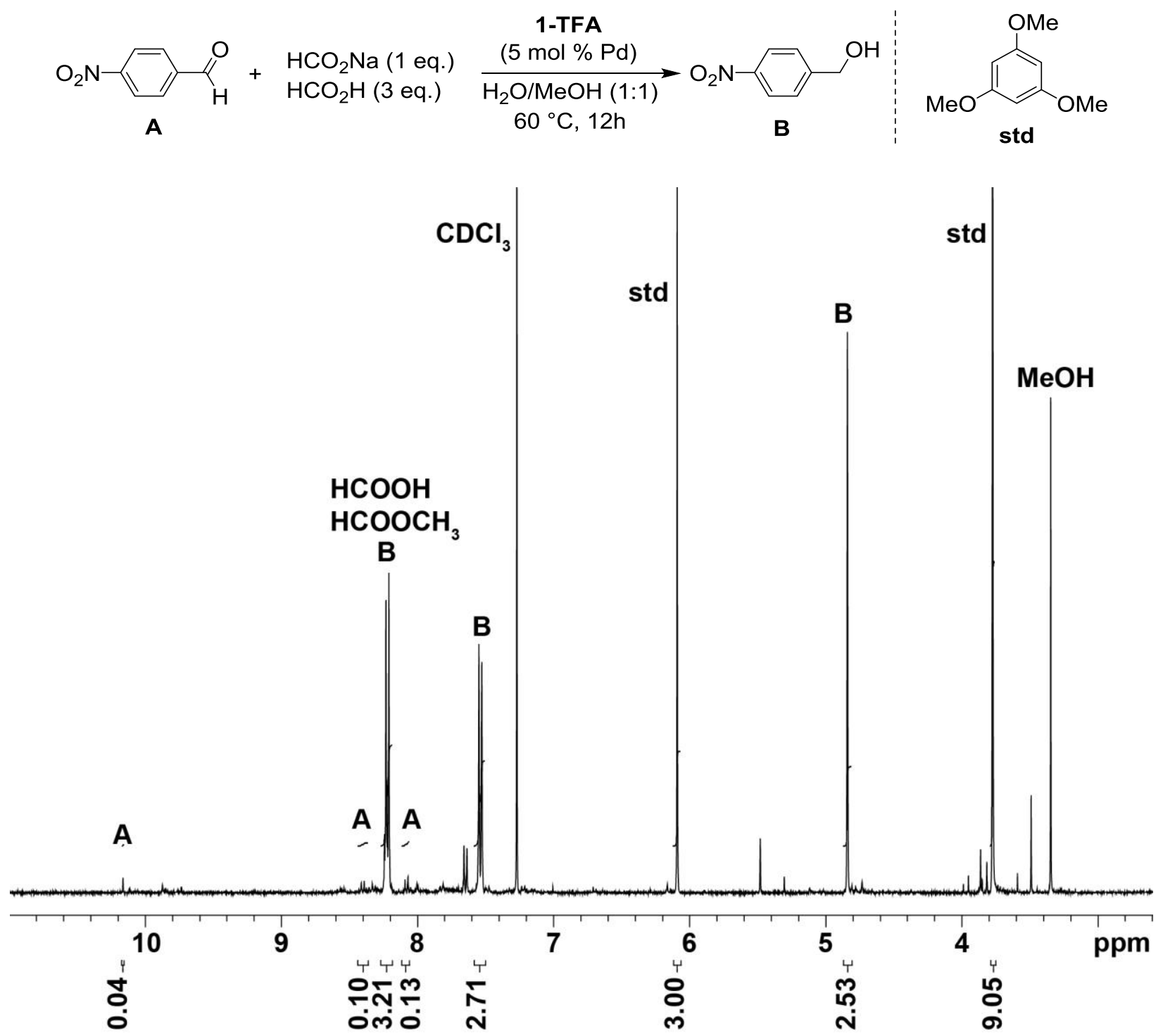

Figure S26. ${ }^{1} \mathrm{H}$ NMR spectrum of $\mathrm{CDCl}_{3}$ extracted products after catalytic transfer hydrogenation of 4-nitrobenzaldehyde (Table S1, entry 4) with 1-TFA (5 mol \%) as catalyst. 


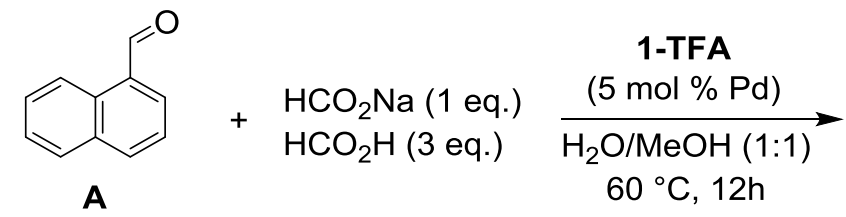<smiles>OCc1cccc2ccccc12</smiles>

B
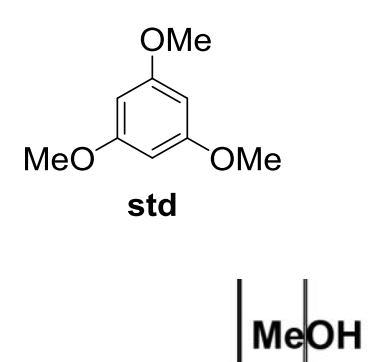

$\mathrm{CDCl}_{3}$

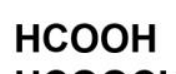

$\mathrm{HCOOCH}_{3}$
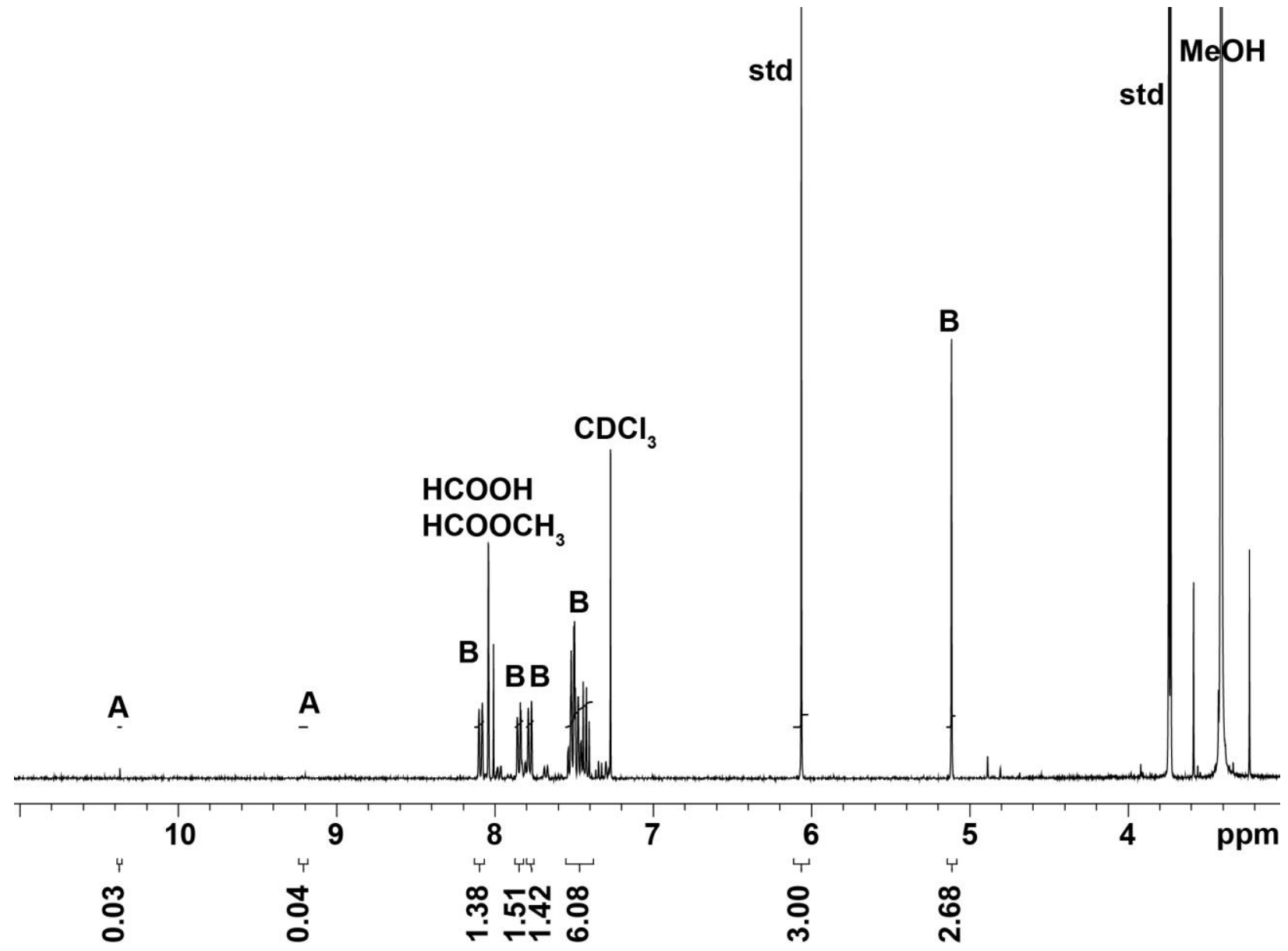

Figure S27. ${ }^{1} \mathrm{H}$ NMR spectrum of $\mathrm{CDCl}_{3}$ extracted products after catalytic transfer hydrogenation of 1-naphthaldehyde (Table S1, entry 5) with 1-TFA (5 mol \%) as catalyst. 


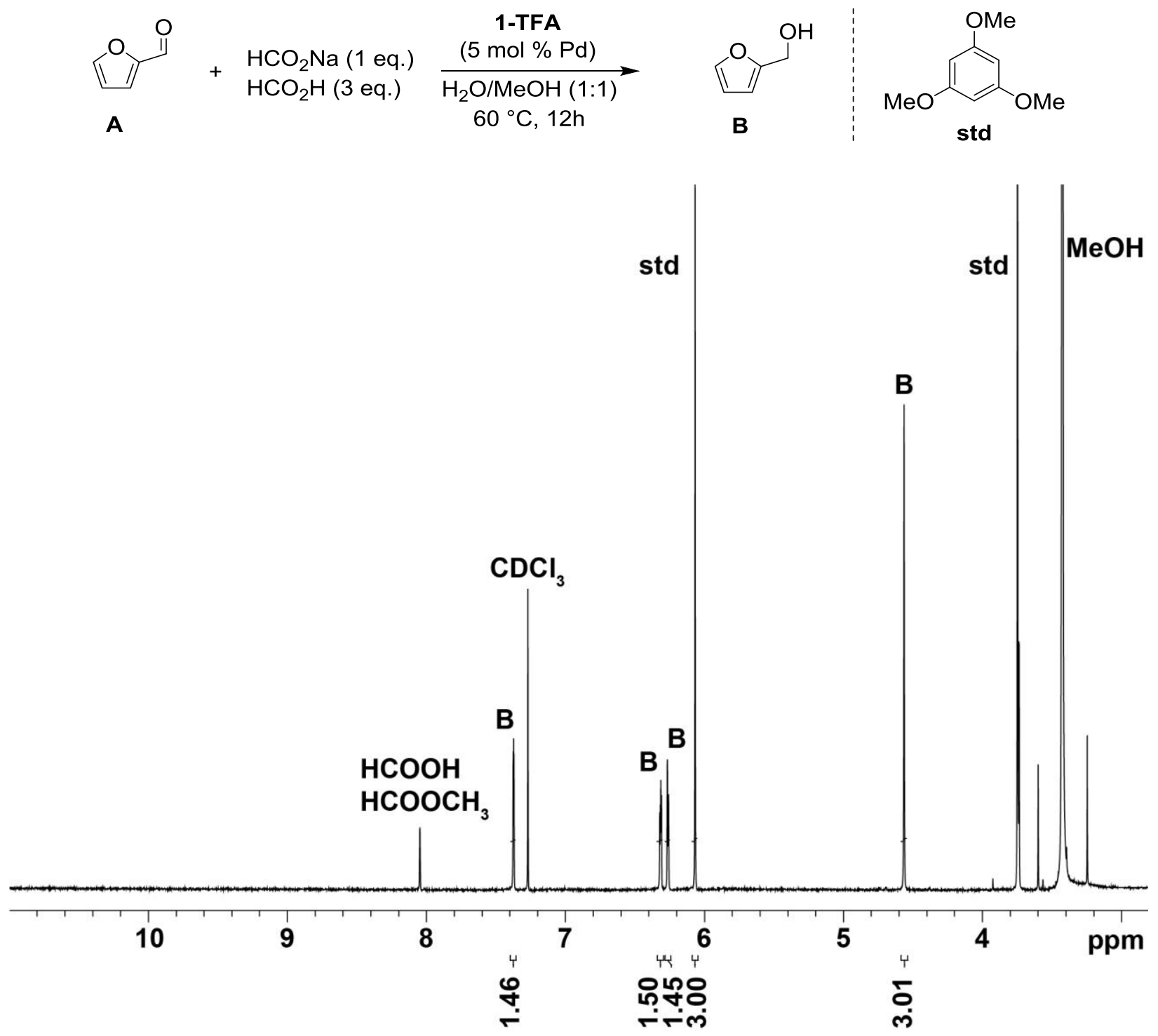

Figure S28. ${ }^{1} \mathrm{H}$ NMR spectrum of $\mathrm{CDCl}_{3}$ extracted products after catalytic transfer hydrogenation of 2-furaldehyde (Table S1, entry 6) with 1-TFA (5 mol \%) as catalyst. 


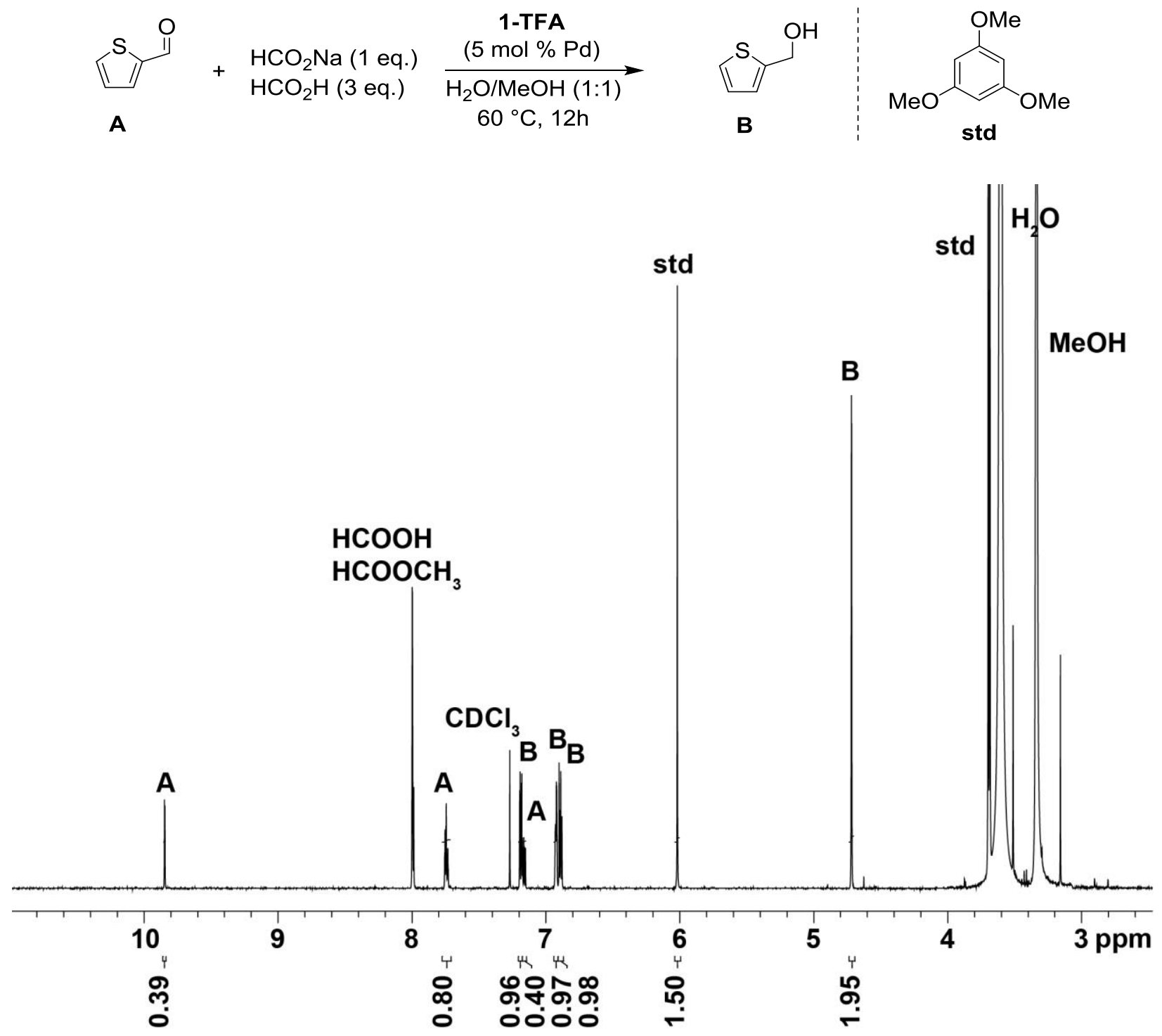

Figure S29. ${ }^{1} \mathrm{H}$ NMR spectrum of $\mathrm{CDCl}_{3}$ extracted products after catalytic transfer hydrogenation of 2-thiophenecarboxaldehyde (Table S1, entry 7) with 1-TFA (5 mol \%) as catalyst. $0.5 \mathrm{mmol}$ of 1,3,5-trimethoxybenzene added as an internal standard. 

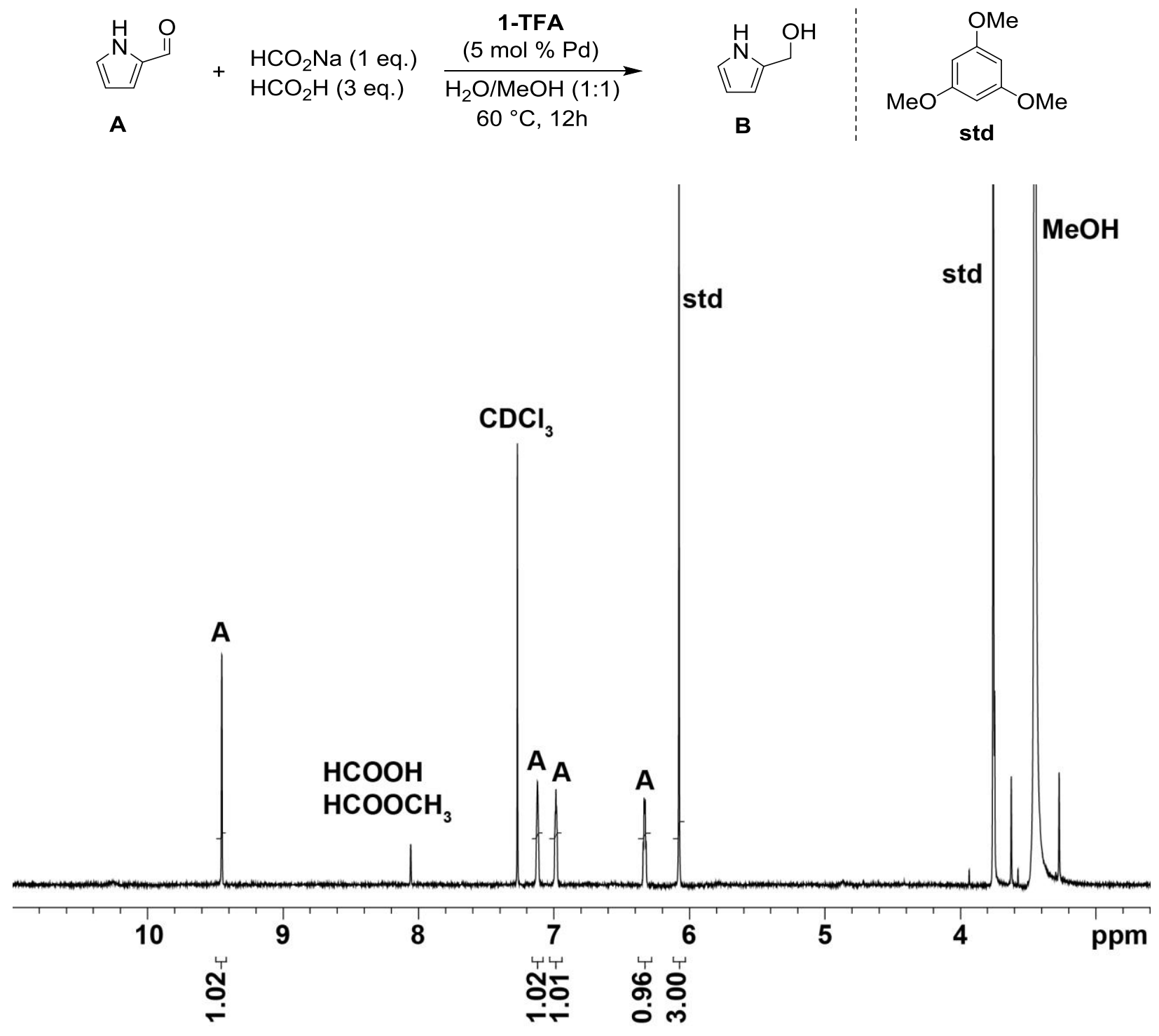

Figure S30. ${ }^{1} \mathrm{H}$ NMR spectrum of $\mathrm{CDCl}_{3}$ extracted products after catalytic transfer hydrogenation of 2-pyrrolecarboxaldehyde (Table S1, entry 8) with 1-TFA (5 mol \%) as catalyst. 


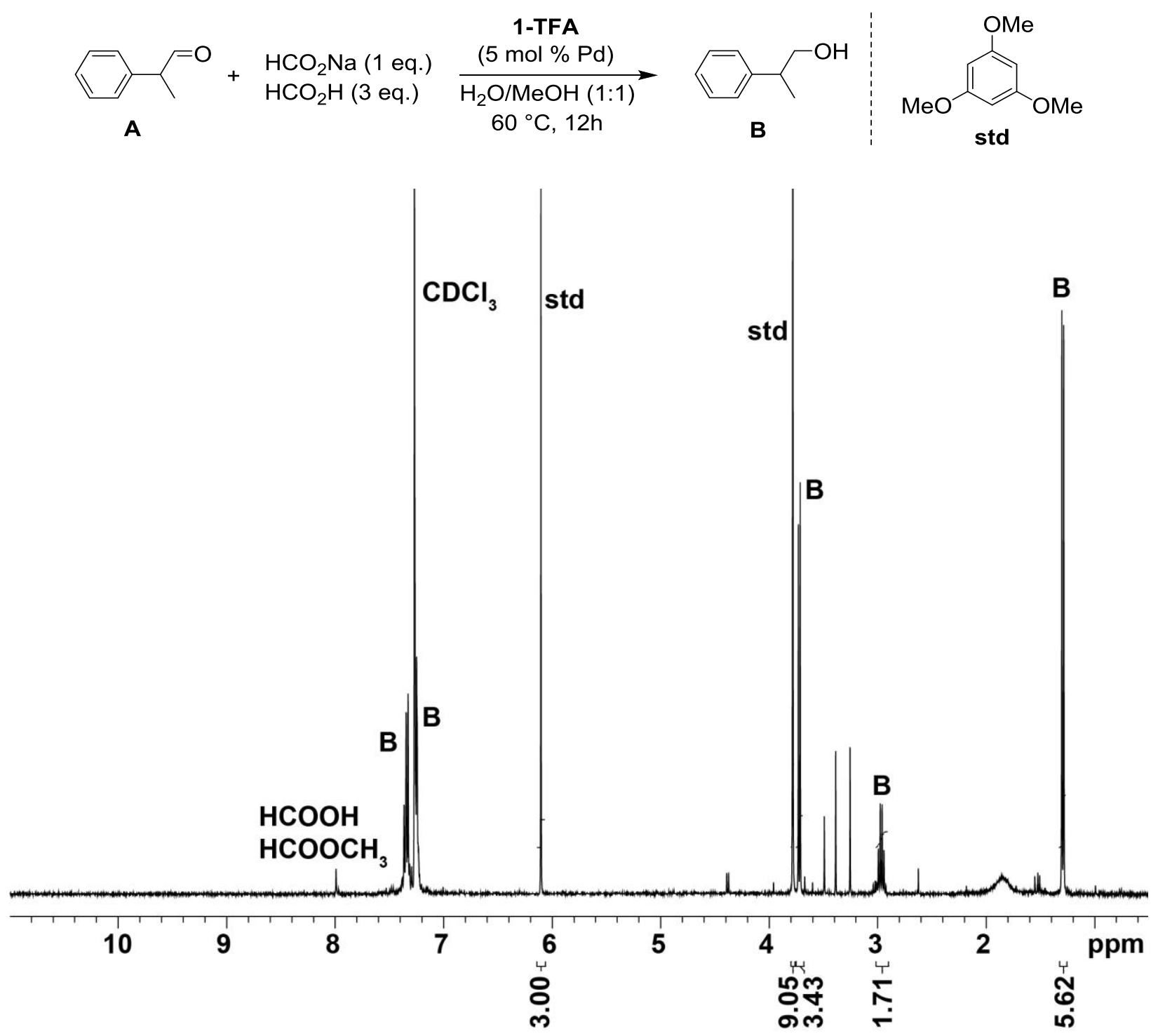

Figure S31. ${ }^{1} \mathrm{H}$ NMR spectrum of $\mathrm{CDCl}_{3}$ extracted products after catalytic transfer hydrogenation of 2-phenyl propionaldehyde (Table S1, entry 9) with 1-TFA (5 mol \%) as catalyst. 


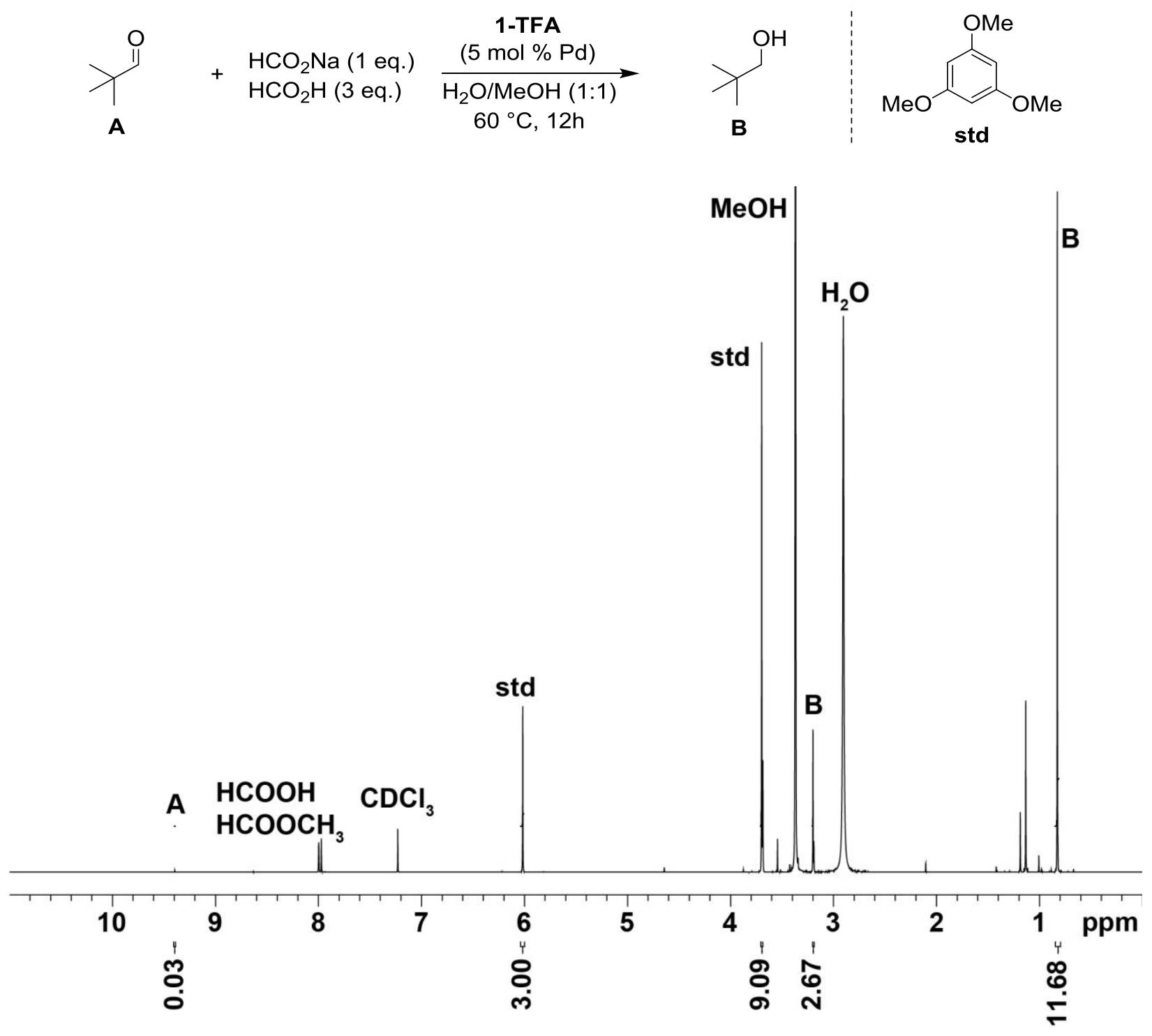

Figure S32. ${ }^{1} \mathrm{H}$ NMR spectrum of $\mathrm{CDCl}_{3}$ extracted products after catalytic transfer hydrogenation of pivaldehyde (Table S1, entry 10) with 1-TFA (5 mol \%) as catalyst. 


\section{Synchrotron Powder Diffraction and Rietveld Refinement of 1-X.}

Powder synchrotron X-ray diffraction data for $\mathbf{1 - X}$ was collected on the 11-BM beamline at the Advanced Photon Source (APS, Argonne National Laboratory). Measurements were taken on a powder sample sealed in a $1.5 \mathrm{~mm}$ diameter kapton capillary at $298 \mathrm{~K}$ using a photon wavelength of $\lambda=0.413959 \AA$. An initial structure model was constructed from the positions of the heavy atoms $(\mathrm{Zr}, \mathrm{Pd})$ located using the charge flipping method within the PDXL 2 Structure Analysis Package (Rigaku Corporation). ${ }^{\mathrm{S} 8}$ Subsequent Rietveld refinement was performed using GSAS as implemented in EXPGUI. ${ }^{\text {S9 }}$

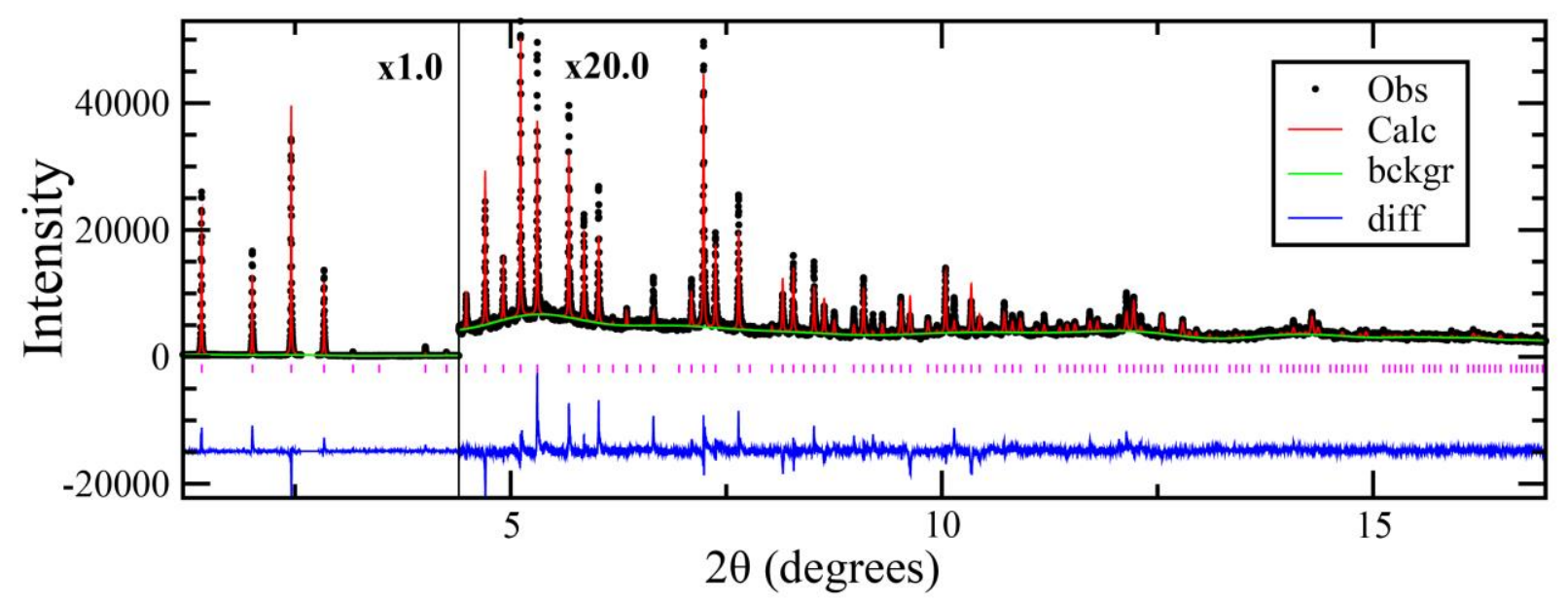

Figure S33. Observed, calculated, and difference profiles from the Rietveld refinement of 1-X $\left(\mathrm{Rwp}=12.9 \%, \mathrm{Chi}^{2}=4.28\right)$. Black dots and red line represent the observed and calculated diffraction patterns, respectively. The blue line represents the difference between observed and calculated patterns, and the magenta tick marks indicate calculated Bragg peak positions. The right hand of the figure shows the high angle region at a magnified scale. Refined cubic lattice constant in space group $P m$-3, is 16.72450 (15) $\AA$ (values in parentheses indicate one standard deviation in the values). The structure is modeled with disorder, and has residual solvent in the pores. 


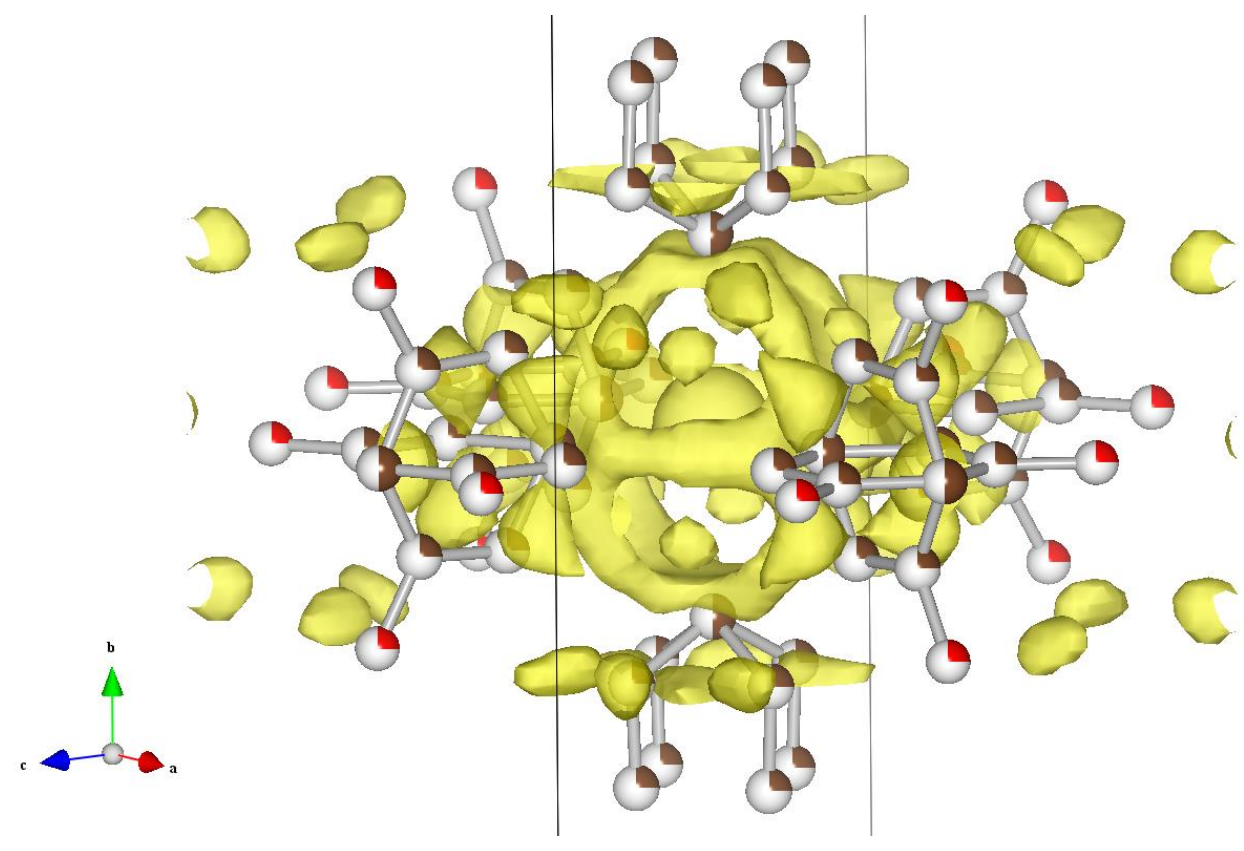

Figure S34. Fourier difference scattering density of the (putative) un-modeled solvent in the large central pore (yellow solid surface) that gives the largest contribution to the residual of the fits in the Rietveld analysis. Partially occupied framework atoms are indicated by spheres and associated bonds. 


\section{References}

(1) Weidelener, M.; Mishra, A.; Nattestad, A.; Powar, S.; Mozer, A. J.; Mena-Osteritz, E.; Cheng, Y.-B.; Bach, U.; Bäuerle, P. J. Mater. Chem. 2012, 22, 7366.

(2) Bowen, L. E.; Charernsuk, M.; Hey, T. W.; McMullin, C. L.; Orpen, A. G.; Wass, D. F. Dalton Trans. 2010, 560.

(3) Tsujiyama, S.-i.; Suzuki, K. Organic Syntheses 2007, 84, 272.

(4) Coulson, D. R.; Satek, L. C.; Grim, S. O. Inorg. Synth. 1972, 13, 121.

(5) Zagulyaeva, A. A.; Yusubov, M. S.; Zhdankin, V. V. J. Org. Chem. 2010, 75, 2119.

(6) Chen, Q.; Hou, S. S.; Schmidt-Rohr, K. Solid State Nucl. Magn. Reson. 2004, 26, 11.

(7) (a) Katz, M. J.; Brown, Z. J.; Colón, Y. J.; Siu, P. W.; Scheidt, K. A.; Snurr, R. Q.; Hupp, J. T.; Farha, O. K. Chem. Commun. 2013, 49, 9449. (b) Wu, H.; Chua, Y. S.; Krungleviciute, V.; Tyagi, M.; Chen, P.; Yildirim, T.; Zhou, W. J. Am. Chem. Soc. 2013, 135, 10525. (c) Shearer, G. C.; Chavan, S.; Ethiraj, J.; Vitillo, J. G.; Svelle, S.; Olsbye, U.; Lamberti, C.; Bordiga, S.; Lillerud, K. P. Chem. Mater. 2014, 26, 4068. (d) Trickett, C. A.; Gagnon, K. J.; Lee, S.; Gándara, F.; Bürgi, H. B.; Yaghi, O. M. Angew. Chem., Int. Ed. 2015, 54, 11162. (e) Oien, S.; Wragg, D.; Reinsch, H.; Svelle, S.; Bordiga, S.; Lamberti, C.; Lillerud, K. P. Cryst. Growth. Des. 2014, 14, 5370.

(8) Schuck, G.; Iwata, A.; Sasaki, A.; Himeda, A.; Konaka, H.; Muroyama, N. Acta Cryst. 2010, A66, S311.

(9) (a) Toby, B. H. J. Appl. Crystallogr. 2001, 34, 210. (b) Larson, A. C.; Dreele, R. B. V. General Structure Analysis System (GSAS), Los Alamos National Laboratory Report; LAUR, 2000, 86. 